\title{
LEO XIII: SEPARATION OF CHURCH AND STATE
}

\author{
JOHN COURTNEY MURRAY, S.J.
}

Woodstock College

I EO XIII developed the theory and practice of Church-State relationships amid the conditions created by the peculiar nineteenthcentury plight of the so-called Catholic nations of Europe and Latin America. ${ }^{1}$ The major feature of the situation consisted in the efforts of an activist ideological sect to effect, through the control and use of governmental power, the politico-social change known as "separation of Church and state." This current phrase was pregnant both of an ideology and of a political and social program. It meant, first, the alteration of the Christian structure of politics, which had been characterized by the traditional duality of Church and state, in the direction of a juridical and social monism. It meant, secondly, the evacuation of the Christian substance of society through the establishment of a surrogate political religion which went by the name of "laicism." The first subject of the present article is separation of Church and state in this pregnant sense, which is the sense in which Leo XIII understood the thing.

The idea of separation was carried in the bosom of the sweeping historical movement which issued from the eighteenth-century lumières as translated by Jacobinism into a political ideology and program. This movement has already been described under its proper name, totalitarian democracy. The purpose now is to bring forward the texts in which Leo XIII gives his understanding of the separation of Church and state at which this movement aimed. A second purpose is to indicate the differences which set off the condemned Continental meaning of the formula from the meaning it has had within the American constitutional system. These differences are numerous and significant. The intention in noting them is initially descriptive. If judgment, whether of approval or of condemnation, is to be passed upon the American constitutional system, it is important that the judgment

${ }^{1}$ Cf., "The Church and Totalitarian Democracy," Theological Studies, XIII (1952), $525 \mathrm{ff}$.; "Leo XIII on Church and State: The General Structure of the Controversy," ibid., XIV (1953), $1 \mathrm{ff}$. 
should be based on a clear appreciation of the uniqueness of this system, which is radically different from the systems familiar to Continental Europe. ${ }^{2}$

\section{TWO TRADITIONS}

Antecedently, it may be said in general that the differences between Continental and American separation derive from a fundamental divergence of political traditions. In our own day research has illuminated the paradoxical fact, not fully appreciated in the nineteenth century, that the spirit, the principles, and the forms of the Christian medieval polity have better survived in the so-called Protestant countries, England and the United States, than in the socalled Catholic states of Continental Europe and their Latin-American derivations. American separation of Church and state owes its special character to the fact that it was conceived within the framework of a political tradition that was directly tributary to the medieval heritage, even though this heritage reached the shores of America

${ }^{2}$ In his work, Instihutiones iuris publici ecclesiastici, II (3rd ed,; Rome: Typis Polyglottis Vaticanis, 1948), 82, the present Cardinal Ottaviani states that the "most common system of separation is that which is enuntiated in the well-known formula, 'A free Church in a free state" "; he adds (ibid., note 1) that this system was proclaimed in Italy by Count Cavour in 1861, but has "obtained in the United States since Sept. 17, 1787." (This is the date of the signing of the Constitution by the Constitutional Convention, which did not become operative till June, 1788, when nine states had ratified it; the Bill of Rights, which settled the relation of Church and state, did not become law till 1791.) Surely this is a misleading statement; one knows what Cavour meant by his famous formula, and an American knows what the First Amendment means. Cavour's formula cannot be used to describe the situation of the Church in the United States. The differences between the Italian republican system and the American system are profound. The difference derives from what Cavour and the United States Constitution respectively mean by the "state," and from what Cavour meant by a "free" state and what the United States Constitution means by a "limited" state, or better, government. Again it is said (ibid., p. 83 and note 1) that in the United States the system of the ius commune obtains. This is quite unwarrantedly to overlook the fact, to which I shall later advert, that the Continental ius commune and the American First Amendment have hardly at all the same juridical meaning, since they respectively repose on widely divergent political theories. Later (ibid., p. 91) it is said: "The formula, 'A free Church in a free state,' established indeed the Church's right to freedom before the state, but it reserves to the state the determination of the sphere of activity within which the Church may freely act." This was indeed the mind of Cavour, in accordance with his concept of state sovereignty; it is not at all the mind of the United States Constitution, which is premised on a very different concept of sovereignty. It is unfortunate that European canonists should intrude European political concepts into the American system, where they have no place. 
in secularized and Protestantized form. In contrast, Continental separation of Church and state, of which Revolutionary France exhibited the exemplar, owed its very different peculiarities to the fact that it represented the final state in the corruption of the medieval political heritage.

This corruption did not begin with "the principles of '89," or even with the Reformation. It began with the beginnings of that state absolutism which became the distinctive mark of the ancien régime, setting it off sharply from medieval polity, whether imperial, royal, or municipal. The most fateful, corrupting consequence of absolutism was the development of the notion of sovereignty as one, indivisible, and omnicompetent. Absolutism enthroned the unchristian principle of the primacy of the political, the supremacy of the raison d'Etat. It led to the irrational idea of law as simply the command of the sovereign. It destroyed the Christian concept of an organic society, whose several orders and institutions have their own autonomy and freedom. It cancelled out all distinction between state and society. It abandoned the principles of medieval constitutionalism. Reviving the lex regia in its degenerate form, absolutism nullified the medieval Christian doctrine of consent. It also wrecked the medieval ideal of representation and of popular participation in power. It fundamentally altered the whole notion of "civil man," turning the medieval homo liber et legalis, who had an intangible charter of freedoms and a real personal existence within his immediate community, into a passive unit who got lost in an undifferentiated mass of "subjects."

Finally, absolutism revived the originally pagan, and later Germanic, notion of the "religion of the state," the Eigenkirche, placed under royal surveillance, and made more or less an instrumentum regni. By the same token it validated the theory of regalism, with all its artful techniques for inhibiting the freedom of the Church. In consequence of a legal rationalization of the whole of public order, effected in the spirit of Roman law, political absolutism forced a new modality upon the Church-State relation, which became a static, formally legal relation, established between sovereignties and regulative of their respective acts, whereas it had been a dynamic, moral, customary relation whose effects had been pervasive through the whole of society. Absolutism was indeed devoted to the cura religionis; there 
would be one faith, as there was one king and one law. But this care of religion was itself largely an aspect of absolutism's fundamental drive towards a monism of state power and law. This drive is inherently destructive of the Christian structure of politics.

Out of the process of the destruction of the medieval political heritage, begun in the absolutist era, there came Gallicanism, the religious Caesarism of the French classical monarchy and of the Spanish Crown, Hispanidad in the sense of Philip II's Inquisition, Febronianism, Josephinism. The reception of Roman Law, to the relative extent that it was a damnosa hereditas, assisted the process. So too did the post-quattrocento nationalisms, and the unprecedented confusion of religion and politics introduced by the Reformers and abetted by Catholic princes. The whole movement gathered force from the sixteenth-century principle of territoriality, from the seventeenthcentury principle of the divine right of kings, from the eighteenthcentury principle of the public good as wholly embodied in the state (of which the enlightened despot was the First Servant and therefore the absolute master, possessor of the total ius politiae), and finally from the nineteenth-century principle of the sovereignty of the people with all its monistic overtones. The destruction of the ancient Christian heritage became complete with totalitarian democracy, which bettered the instruction of the ancien régime in point of state monism and an absolutism of political rule.

In one decisive aspect the rise of the absolutist national monarchies progressively turned the medieval situation inside out. The traditional structure of politics had been marked by a distinction between society and state. This political distinction was a historical development consequent on the Christian distinction between state and Church. This latter distinction established the principle of the freedom of the Church. Since in medieval times the Church itself was the Great Society, free under its own law, there was inherent in the freedom of the Church the concept of a free society, a whole area of human concerns-the sacred concerns of man and also those temporal concerns which have a sacred aspect - which had its own structure in terms of man's original rights and responsibilities. This area was marked off as being outside the legitimate sphere of interest of the secular power. The power itself stood within the Great Society, as a limited aspect of its ad- 
ministrative life, constituent of a minor order distinct from the order of the Great Society, set to serve the order of the Great Society.

Royal absolutism reversed this situation. The whole of society, including the Church, was drawn inside the growing state and gradually surrounded by the developing armature of civil law. Society became the particular nation; the nation was identified with the state; and the nation-state itself became identically the Great Society. The political result of the development was the "society-state," the one all-embracing omnicompetent form of human association. In it the state-aspect - the aspect of power and law-increasingly assumed the primacy over the society-aspect, the aspect of culture, education, associational life (including marriage and the family), and even religious life. Totalitarian democracy represented the end-form of this lengthy corruption of traditional political principle. Amid the jumbled ambiguities of the Third Republic (and its Continental and Latin-American imitations) hardly a vestige of the medieval political heritage remained visible. It was in the conditions created by this disintegration that Continental separation of Church and state took its rise and assumed its special character. In these conditions, characterized by the omnipotence of the society-state, the separation of the state from the Church inevitably involved an apostasy of society from the Catholic religion. Being separate from the state, the Church could have no existence within society, except such as the sovereign power might choose to grant it.

Continental separation was also the outgrowth of another development-I mean the movement towards a redivinization of society which was intimately related to the movement toward the absolutization of the state. In a brilliantly argued thesis Eric Voegelin has pointed to this development as constituting "the inner logic of the Western political development from medieval immanentism through humanism, enlightenment, progressivism, liberalism, positivism, into Marxism."” The movement claimed for itself the name of "progress"; actually, at its most profound level it represented reaction. It was a repudiation of the central civilizational tradition of the West.

The essential political impact of Christianity had consisted in a

s Eric Voegelin, The New Science of Politics (Chicago: University of Chicago Press, 1952), p. 125. 
radical de-divinization of the temporal sphere of power. Christianity brought a new truth, a new hope, a new law, and a new community. In the name of these new things it denied that the state represents the ultimate milieu of man's perfection, the embodiment of the highest values in human life, a moral end in itself, and the sphere for the achievement of salvation. It denied too that secular government is the existential representative of ultimate truth. "Dux hominibus esse ad coelestia, non civitas sed Ecclesia esse debet," as Leo XIII succinctly phrased the tradition. However, this Christian devaluation of the civil power and of the temporal sphere of its exercise has continually met resistance. The resistance is part of the permanent recalcitrance to the Gospel -its truth and its grace - which is inherent in unregenerate nature, and in nature even when regenerate.

The resistance has taken many historical forms, not least in Catholic empires and states. ${ }^{4}$ But it assumed its most self-conscious and organized form in the modern religion of laicism. The name is misleading. The "man" of this religion is not the lay man but the divinized man of rationalist theory. The "society" of this religion is not a secular but a sacralized society - a society invested with the historic religious functions of the Christian Church, which are to teach man the full truth and to lead him to salvation. Laicism was the religion of selfsalvation, wherein man becomes God and society becomes the Church. It is indeed customary to speak of the secularization of politics as the specific modern phenomenon. A more revealing term would be the sacralization of politics, or the redivinization of society, meaning the elevation of the society-state to the level of a quasi-religious form of life, wherein the ultimate good, "salvation," is to be achieved. Continental separation of Church and state was an essential aspect of this movement toward the redivinization of society. Unless this is understood, its meaning cannot be grasped. So Leo XIII understood it, as will appear.

4The first formal, and very formidable, theorist of reaction against the Christian devaluation of politics was, of course, Marsilius of Padua: "The Marsilian state remains as an illustration of what the state might have been, if, besides the Aristotelian influence, other and vital motives had not been contained in the legacy of medieval political thought, if new ideas and forces had not grown up from the very core of our Christian civilization to limit and neutralize the pretence of the state to embody the ultimate value of human life" (A. P. d'Entrèves, The Medieval Contribution to Political Thought [Oxford University Press, 1939], p. 87). 
The immediate point here is that the American political tradition, whose parentage was English rather than Continental, has remained substantially untouched by the two radical vices which ruined the medieval heritage on the Continent-absolutism and the sacralization of politics. ${ }^{5}$ The link of continuity with the great tradition has indeed been weakened; in America too there has been a certain treason of the clerks, although its results have never been so radical as they were on the Continent. A most urgent intellectual task confronts those Americans who see that the future of their political experiment depends on the success with which its principles will now be restated in their deepest connection with the ancient patrimony. ${ }^{6}$ What is centrally significant, however, is the fact that the link with this patrimony, for all that it has grown tenuous, has never been broken. In consequence, the American constitutional system, as a structure, still reveals the essential lines of the Christian structure of politics. Furthermore, the American idea of the political order in its relation to the larger order of human social living, in remaining untainted by sacralization, has remained substantially true to the great tradition.

Decisive here is the firmness with which the United States Constitution asserts the distinction between society and state and the principle of a government of limited powers. The American people have repudiated the Continental concept of the omnicompetent

${ }^{5}$ It must be understood that $I$ am here speaking of the political form of American government, not of the mores of American society; this latter subject is quite different, and unconnected. It should also be remembered that in the United States separation of Church and state belongs to the "political form of the public powers" and not to the "legislation" (to use the distinction made classic by Leo XIII in the Encyclical, Au milieu, when he urged French Catholics, notably the recalcitrant Right, to accept on principle the political form of the Third Republic and concern themselves rather with altering its legislation). The reason is that American separation, unlike Continental separation, is linked indissolubly to the notion of a government of limited powers - powers limited by popular consent. This is a defensible political concept. Continental separation was linked to the notion of a government of unlimited powers, as Leo XIII brought out very clearly. This is an altogether indefensible political concept.

${ }^{6}$ As part of the retheoretization of the American way of life that is going on today there is taking shape a theory of separation of Church and state which begins to resemble nineteenth-century Continental theories; it represents a departure from the original principles of American constitutionalism. This is a disturbing development. It is not evident to me how the development is to be combatted by those American theologians who seem to maintain that the American system is quite the same as the Continental system-a hypothesis meriting the same measure of toleration which the Holy See manifested toward Continental separation. 
society-state. The consequence is that the state remains interior to society, not outside of it, as it were, and surrounding it. The state is an aspect of the life of society - a pervasive aspect (as modern law is pervasive) but not an all-embracing or omnicompetent aspect. The state stands in the service of society and is subordinate to its purposes. It is limited even in its office of ministry-limited by a whole structure of personal and social rights not of its creation, and limited too by the principle of consent. The state is not primatial; society possesses the primacy over the state. And in the sense that the spiritual is located in society, not in the state, the principle of the primacy of the spiritual over the political holds sway. Moreover, the channels for the enforcement of this primacy exist in the form of popular institutions of rule, through which the conscience of society makes itself the norm for the action of the state.

Within this structure of politics the American concept of separation of Church and state finds place. It is a consequence of the distinction between society and state. It is a consequence of the fact that society, the people, has made to government only a limited grant of powers. It is a consequence of the general theory of a pluralism of powers whereby society is directed. Undoubtedly the distinction between Church and state is exaggerated. But it is one thing to exaggerate a distinction into a separation, as in the American case; it is quite another thing to obliterate the distinction in a false unification, as in the Continental case. In the American case the essential lines of the medieval structure of politics are still somehow visible; in the Continental case they are destroyed utterly.

Furthermore, American separation of Church and state, unlike the Continental brand, neither implies nor effects any sacralization of politics. The First Amendment has no religious overtones whatever; that is, it does not imply any ultimate vision of the nature of man and society. It does not veil any pretence on the part of the state to embody ultimate values. It does not imply that there is any virtue in society whereby it can save itself, become a good society, in separation from religion. Its purpose is not to separate religion from society, but only from the order of law. It implies no denial of the sovereignty of God over both society and state, no negation of the social necessity and value of religion, no assertion that the affairs 
of society and state are to be conducted in disregard of the natural or divine law, or even of ecclesiastical laws. It is not a political transcription of the religion of laicism. It is a legal rule, not a piece of secular ecclesiology.

It does not make the state a church, nor does it establish a political religion. It does not envisage an evacuation of the Christian substance of society; it simply imposes restrictions on the legal activity of the state. It has an effect quite opposite to that of Continental separation. So far from sacralizing the political community or the legal order, it secularizes both. That is, it confines law and government to secular purposes (which are understood to include the moral purposes of freedom, justice, peace, and the general welfare). The American concept therefore does not derive from the Continental movement towards a redivinization of the society-state. It stands more directly in continuity with the central Christian civilizational tradition-the tradition of revolt against the sacralization of the political order, and of insistence on its status as secular. You may say that it carries this revolt, this insistence, too far. However, it is one thing to carry a tradition too far, but still in its own line; it is quite another thing to subvert the tradition entirely, and inaugurate a fundamentally divergent tradition. Certainly the effects of the two procedures have been, from the standpoint of the Church, spectacularly different.

The foregoing general confrontation of two concepts of separation has been made, as I said, for the purposes of description and differentiation, and with a view to pointing out the root of difference. It will appear from what follows that Leo XIII condemned Continental separation for a variety of reasons, all of which were related to its root. This vitiating root is not the source from which the American concept of separation took its origin.

Perhaps at the outset note should be taken of an objection. There may be those who will wish to foreclose discussion by saying that separation of Church and state is always and everywhere per se damnable; therefore any attempt to distinguish American and Continental concepts, and all this appeal to divergent political traditions are so much waste of time. Their reason will be that the Catholic Church is the one true Church; that separation of Church and state denies this truth; that separation is therefore damnable. In reply, I 
can only allege the authority of Leo XIII. His massive corpus on the subject does not offer evidence that would justify the reduction of the argument to this simplisme.

For an individual to deny, in the face of the revealed truth known to him, that the Catholic Church is the one true Church is indeed heresy. For society to make this denial, again in the face of the truth individually known, would be what Leo XIII calls a social apostasy. This is most certainly true. But the fact is that Leo XIII did not locate the root-principle of separation of Church and state in this naked denial of a revealed dogma, as if somehow separation immediately flowed from this denial. Obviously, la philosophie denied that the Catholic Church is the one true Church. This is the reason why the philosophers themselves personally rejected the Church. But this is not the immediate reason why the Jacobin politicians, who followed the philosophers, sought to alter the traditional relation between Church and state. The reason was because they gave a political transcription to their philosophy, in the form of totalitarian democracy, a unified society-state, monist in its structure, pseudo-religious in its substance.

It was upon this political conception that separation of Church and state immediately followed. It was in accord with this political conception that Continental separation assumed the special character lengthily described by Leo XIII. It was because of the vices inherent in it by reason of its political principle that Leo XIII condemned it. Its monist totalitarianism shattered the traditional structure of society, which rests on the distinction and ordered relation of Church and state. Its pseudo-religious substance expelled the true substance of society, which is constituted by the heritage of Christian and rational truth. Disestablishment of the Church was indeed part of the process of separation. But even this disestablishment did not follow immediately upon a theological denial of the nature of the Church. It followed immediately on a political assertion about the nature of the state - the assertion of a self-sufficient monism of society, law, and sovereignty. That this is the heart of the matter will appear from the evidence. There can be no objection to efforts to distil, as it were, the juridical essence of separation. There may be objections to the definition of this juridical essence as consisting in the absence of legislation 
constituting Catholicism the religion of the state; there was a dispute among canonists on this point in connection with the Portuguese Concordat. ${ }^{7}$ The important thing, however, is to be aware that the real essence of separation is not juridical. This awareness is required, unless one is to do violence to the thought of Leo XIII.

\section{LEO XIII ON SEPARATION}

Leo XIII's first mention of the term, "separation," proves his grasp of the problem that he faced. It occurs in a letter to Cardinal Nina, Secretary of State, written a few months after his coronation: "We said that the most powerful cause of all this ruin lies in the proclaimed separation and the attempted apostasy of present-day society from Christ and from His Church, in which alone there resides a virtue sufficient to make good all the disastrous social losses." coupling of the notions of "separation" and "social apostasy" indicates the complexity of the problem. There is the problem of the alienation of the public power: "... potestatis publicae saepe ab Ecclesia aut aversa voluntas aut aperta defectio." In Christian Europe the public power had turned its back on the Church or openly deserted it. More is implied here than is meant by separation of Church and state in the narrow juridical sense of the disestablishment of the Church. The apostasy of the power was not unto simple unbelief, neutrality, or indifference, but unto an alien faith, a new political

${ }^{7}$ Cf. Yves de la Brière, "Le Concordat du Portugal," Construire (1941), p. 244.

${ }^{8}$ Letter, Da grave sventura (1878), Leonis Papae XIII Allocutiones, Epistolae, Constitutiones, I (Paris: Desclée, 1887), 37. (This edition is hereafter cited as "Desclée.") The notion of social apostasy appears elsewhere; for instance, in the Letter, $E$ giunto: "On previous occasions in public documents addressed to the Catholic world We have demonstrated how erroneous is the doctrine of those who, in the seductive name of freedom of worship, have proclaimed the legal apostasy of society from its divine Author" (Desclée, III, 266). The juridical act implied in the Continental ius commune (against whose introduction into Brazil the Pope protests in this Letter) was indeed the act of a legal apostate, sc., the totalitarianizing sovereignty itself, which brought in its train a social apostasy, given the political fact of the unified society-state. (No American would maintain that the First Amendment is an act of legal apostasy, or that it implies an apostasy of society. It was simply - if the repetition may be excused-an act of the people limiting the powers of government.) On another occasion, writing to Cardinal Rampolla, after one of his many resumés of the Masonic "plot" in Italy, the Pope recurs to the notion of social apostasy: "And will all this perhaps mean the triumph of the Italian cause-or rather the advent of an apostasy?” (Desclée, VI, 99).

${ }^{9}$ Encyclical, Quod multum (1886), Desclée, II, 220. 
religion. The power now stood in the service of a militant secular faith.$^{10}$ Hence there followed the second and more important problemthat of the apostasy of society in the whole range of its institutions. The apostate power was to be the instrument of this social apostasy, this collective attempt to abandon the traditional Christian foundations of society and erect a new structure on purely secular bases. This was the larger, more crucial problem.

Although Leo XIII practically never uses the classic distinction between state and society, it is implicit in his view of the architecture of the problem that confronted him. It is also implicit in the structure and orientation of his doctrine and action. In fact, the lines of his doctrine and action would gain greatly in clarity if this distinction, implicitly made, were brought to explicitness. The outstanding historical merit of Leo XIII, and the brilliant witness to his breadth of view, lay in the fact that he subordinated the problem of Church and state in the narrow juridical sense to the problem of the Church and human society in the broadest sense. There is no doubt that Leo XIII set very great value upon legal and diplomatic relations between the Church and civil governments; as I shall later say, in speaking of the action of the Pope, this was the primary problem from a tactical point of view. However, for all its importance, the solution of the juridical problem was a means to a wider end, the rechristianization of society, its recall from its apostasy to the natural and supernatural truths which are the necessary basis even of social salvation. Whatever value Leo XIII set on legal and diplomatic relations with governments lay in their contribution to this supreme spiritual end.

The reference in Da grave was to the theme of Inscrutabili. This Encyclical is usually entitled, "On the Evils of Human Society." A title more indicative of its content, and of the new positive note that it struck in pontifical literature, would be (in a phrase from the text itself), "On the Church as the Mother and Mistress of Human Civilization." There is no reference to separation of Church and state in the narrow juridical sense. The problem envisaged is broader: “...

${ }^{10}$ The notion of a "substitute faith" is constantly present in the numerous texts on the Masonic sect, which the Pope considered to be the bearer of a new sort of pseudo-religion; cf. particularly, Encyclical, Dall'alto (1890), Lettres A postoliques de Léon XIII, Encycliques, Brefs, etc. (Paris: Maison de la Bonne Presse), VII, $96 \mathrm{ff}$. (This edition will hereafter be cited as "Bonne Presse.") 
the widespread subversion of the supreme truths on which, as on its foundations, the stability (status) of human society depends...." This is the problem of the treason of the clerks, who have deserted to a new allegiance, the power of unaided reason as completed by the power of government. Leo XIII lays emphasis on the fact that a principal subversion consisted in the rejection of the authority of the Church. In consequence, ultimate supremacy was accorded to secular government, whose inspiration was "the impudence of those who, although they greatly err, put up the pretence of being the champions of the fatherland, of freedom, and of all manner of right."12 The political and legislative depredations of this new omnipotence are given in some detail, in obvious dependence on events in France, Italy, and Germany. Already therefore in Inscrutabili there is touched that cardinal element in the ideology of separation which Leo XIII constantly signalizes as characteristic. He calls it the "new regalism":

If one takes a look at the record, what is the trend today? It has become a general habit to regard the Church with suspicion, distaste, hatred; to make charges that cast odium upon her. What is much more serious, every effort and resource is employed to make her subservient to the sovereignty of political rulers. Hence her properties are confiscated; her freedom is restricted; difficulties are thrust in the way of the education of aspirants to the priesthood; the clergy is subjected to laws of exceptional severity; her valuable auxiliaries, the religious congregations, are dissolved and outlawed. In a word, the maxims and practices of the regalists have been reinforced with new harshness. ${ }^{13}$

Fourteen years before this statement, the same name, "regalists," was used of the theoreticians of the "new matrimony" within the framework of the new political religion. ${ }^{14}$ They distinguished between the nuptial contract and the sacrament, took the contract under the sole jurisdiction of the state, and left to the Church the function-to them, idle - of blessing the parties.

"Encyclical, Inscrulabili (1878), Desclée, I, 5. Note that the adherence of Leo XIII, or his scribes, to classical Latinity forbade the use of the word "status" in a political sense. The words used are respublica, civitas, societas, societas civilis, civilis communitas, etc.-all of them used indiscriminately to mean either state or society or government or the political power in general.

${ }^{12}$ Loc. cit.

${ }^{13}$ Apostolic Letter, Praeclara grahulationis (1894), Bonne Presse, IV, 96-98.

${ }^{4}$ Encyclical, Arcanum (1880), Desclée, I, 131. 
The name, "regalists," applies with genial appropriateness to the theoreticians of the Continental concept of separation. However, Leo XIII does not trace the direct line of continuity between the new regalism of the Revolution and the old regalism of the classic Catholic state, so called. ${ }^{15}$ The continuity lay in the shared notion of the society-state, a political notion that conferred upon the state a competence, if not in "religion," at least in "ecclesiastical affairs" (as the received distinction had it - a distinction by no means clear in itself or in its applications). The new separation of Church and state and the old Union of Throne and Altar, whatever their differences, had one thing in common - a tendency toward the politicization of the whole of society, religious matters not excluded. It was with this tendency of the Continental state that the American political experiment broke, by a return to the older Western distinction between society and state. In the American concept of separation there is no trace of regalism, old or new.

The Continental meaning of separation is further developed by Leo XIII in the Encyclical, Quod apostolici, against the socialist sect. The facet that here emerges is the essential link between separation as a political doctrine and the rationalist ideology of the Enlightenment, with its theory of the absolute autonomy and omnipotence of reason. (The Pope objects to using the word, "reason," in connection with this ideology; he understands it to be simply what is called today "the theory of passionate existence.") This ideology, he says, has not only taken possession of individual minds; it has become a theory of society:

In consequence, by a new sort of impiety unknown even to pagans, societies are organized without any regard for God or for the order established by Him. The assertion is repeatedly made that the public power owes neither its origin nor its majesty nor its power of command to God, but rather to the multitude. Furthermore, the multitude considers itself to be independent of all divine ordinances; and it permits itself to be made subject only to those laws which it has itself enacted at its own pleasure. The supernatural truths of faith are attacked and rejected as hostile to reason; and by a slow and gradual process the Author and Redeemer of

${ }^{15}$ In the Allocution, La devozione (1889; Desclée, III, 227), the Pope protests against the revival of the regalist exequatur and the regio patronato by the anticlerical government in Italy. 
the human race is forced into exile from both higher and lower education and from all the public usages of human life..$^{16}$

Behind this text one can see the whole theory of totalitarian democracy. There appears the Jacobin theory of "the people," as meaning the Jacobins themselves and their good friends. There also appears the distinctive Continental theory of the sovereignty of the people, understood in the sense of Rousseau. Finally, there appears the naturalist deformation of the ancient Christian doctrine of consent. The absolutism of sovereignty claimed by the old rex legibus solutus, monarch by divine right, is now claimed by "the people" in the Jacobin sense, with the difference that the new sovereignty is absolute by right of "reason," which in the philosophy of the Enlightenment has become the divine majesty. This collective reason is legibus soluta in an altogether radical sense. It is also monist in that it allows no other sovereignty over the society-state; it rules entirely and it rules alone. The political result is separation of Church and state, as meaning the exile of God from society, and the complete irrelevance of divine law, revealed or natural, in what concerns the structures and processes of organized social life.

Moreover, this exile does not imply that a vacuum is to be left; actually, God is crowded out by an ideology which, under rejection of Him, itself pretends to furnish the foundations and substance of society. This notion of the exile of God and the banishment of the Church from society is constantly alluded to by Leo XIII as characteristic of the separation he condemns. The notion goes far beyond anything implied by separation in the technical juridical meaning.

It may be remarked here that the famous American constitutional phrase, "We, the People. ..," is the very negation of Jacobinism. The American concept of "government by the people" does not attribute to the people the divinity implied in the Revolutionary idea of "the sovereignty of the people"; it simply embodies the ancient principle of consent in a developed and still recognizably Christian sense. The American system neither supposes nor effects an exile of God from society. Finally, the state itself, in its distinction from society, rests

${ }^{16}$ Encyclical, Quod apostolici muneris (1878), Desclée, I, 51-52. 
on no pretence that even political life can be organized "without any regard for God or for the order established by Him." On the contrary, the Constitution of the U. S. has to be read in the light of the Declaration of Independence, in which there is explicit recognition of God and of an order established by Him - the order of human rights, which is part of the universal moral order to whose imperatives the political order must be obedient. The phraseology is indeed touched with the flavor of the Enlightenment, but it is in no sense redolent of Jacobinism. It states a traditional idea.

Further clarification of the Continental concept is furnished in Leo XIII's Letter, $\mathrm{C} i$ siamo, protesting against the Italian law which made the religious celebration of matrimony a penal offense. The premise of the law was the affirmation that "matrimony is a creation of the state, and nothing more than a common contract and a social cohabitation, entirely of a civil character." 17 As a purely civil affair, therefore, marriage is to be "separated" from the Church, which is to retain only the right of giving a private ritual blessing. The Pope attributes the theory to the "sworn vassals of the autocracy of the state." 18 This example is illustrative of the juridical monism that was inherent in the separatist theory and practice of the unified society-state. The only law is the civil law; ecclesiastical law is not a source of juridical values. Furthermore, in analyzing this example the Pope brings out what I have called the political religion of separatism, here shown in its pretence of constituting an autonomous morality of society:

From all this you will understand, Venerable Brethren, what judgment is to be formed of a Catholic state which throws overboard the sacred principles and the wise enactments of the Christian law on matrimony, and sets about the wretched job of creating a marital morality all its own, purely human in character, under forms and guarantees that are merely legal; and then with all its power goes on forcibly to impose this morality on the consciences of its subjects, substituting it for the religious and sacramental morality, etc. ${ }^{19}$

\footnotetext{
${ }^{17}$ Letter, Ci siamo (1879), Desclée, I, 86.

${ }^{18}$ Ibid., p. 87: "ligi all'autocrazia dello Stato."

${ }^{19}$ Ibid., p. 88. This text illustrates the conventional, non-political, and-one must think-rather ambiguous use made by the Pope of the term, "Catholic state." On the Pope's own showing the Italian state and its government represented practically nothing Catholic in its inspiration, principles, and action. What the Pope means, of course, is that in Italy the community was predominantly Catholic; the population was largely Catholic. Political vocabulary distinguishes between "state" and "community."
} 
The society-state is to have its own morality, "separate" from Christian morality: "They have dared to say without ambiguity that social morality is not religious morality, and that the civil legislator is not to act as a moralist in constituting it," but simply as an official of the state. ${ }^{20}$ In other words, social morality is simply legality; its source is the civil law, the will of the legislator, who has no higher norm than his own will. This example well illustrates what I meant by speaking of the new substance of society which the Continental concept of separation sought to create. It is hardly necessary to say that, whatever may be the defects of the American civil code (and they are many, not least in regard of matrimony), the code itself rests on no such premise as this-the premise of an utter divorce between civil law and moral law, which means, in the practice of civil life, the absolute priority of the civil law.

In the light of this example one can better understand what was in Leo XIII's mind when he speaks of "the principle of separation of Church and state - which is equivalent to separating human legislation from the divine and Christian legislation." ${ }^{21}$ The initial principle of the theory and its basic absurdity is the omnipotence of the political sovereignty. Logically consequent is the absurdity of positing the omnicompetent civil law, which is held to be the one and only law, as an independent source of morality. Further consequent is the absurdity of establishing between this pseudo-source of morality and the true source, the divine and Christian law, an absolute separation, a great impassable gulf, in such wise that no reciprocal influence is permissible or possible. Legal enactments are not to reflect the higher law; the higher law is without relevance to the legal order, which is the total all-embracing order of society. This theory of total separation is altogether different from the Christian jurisprudential theory which admits that a certain variable distance, as it were, may obtain between the civil code and the precepts of divine and Christian law, in consequence of the actual state of the popular conscience and the exigencies of the common good - the "public utility," as St. Thomas calls it. ${ }^{22}$ Again I would remark that none of the absurdities of the theory of total separation-above all not its cardinal principle of

${ }^{20}$ Ibid., p. 90.

${ }^{21}$ Encyclical, Au milieu (1892), Bonne Presse, III, 121.

${ }^{22}$ Cf. I-II, q. 96 , a. 2 c. 
omnipotent state sovereignty - are to be found in the American constitutional and legal system.

This same idea of a monist indivisible sovereignty, all-embracing in its control over the society-state and creative of the very substance of society, lies behind the text in the Encyclical, Cum multa, to the Spanish bishops. This text is a brief introduction to a reproof, which the Pope had several times to administer, of the traditional Spanish tendency to confuse religion and politics:

It will, first of all, be in place to recall the mutual relations of sacred and civil affairs, because many fall into contrary errors. Some are wont not only to distinguish political affairs from religion but completely to sever and separate them. They wish the two to have nothing in common; they think that neither should have any influence on the other. These men do not greatly differ from those who are in favor of a society which would be constituted and ruled under banishment of God, the Creator and Lord of all things. Their error is the worse for the reason that they recklessly hold society apart from a source of rich benefits. When religion is taken away, the stability of the principles on which the public good depends must necessarily begin to waver; for these principles receive their strongest support from religion. Chief among these principles are the following: that government should be just and temperate; that obedience should be a matter of conscientious duty; that the passions should be controlled by virtue; that to each should be given his due; that no one should lay hands on what belongs to another. ${ }^{23}$

Here again one sees the essence of Continental separatist theory. The question here is not disestablishment-the detachment of the Church from a place in the legal order as the religion of the state. In question is the root-principle of separation in its pregnant sensethe constitution of a quasi-religious concept of the society-state as selfenclosed and completely autonomous, ruled by a single sovereignty than which there is no higher sovereignty. This society-state undertakes to base both its political and its social life on principles of its own creation. It claims to have a theory of civil rule and obedience, and an ideal of civic virtue and justice, which owe nothing to religion. In other words, it has an ethical substance of its own, separate from the substance of religion. It has a monistic structure of its own, and it shuts religion completely out of this structure; or, if religion enters, it becomes subordinate to the single sovereignty. The processes of this

${ }^{23}$ Encyclical, Cum multa (1882), Desclée, I, 316-17. On the Spanish confusion of religion and politics, cf. the Letter, Postquam catholici (1894), Desclée, VI, 5. 
politico-social entity are completely "free," that is, they may not in any way be directed or corrected by religion - by religious authority or by religious principle. This is the Continental "separate" societystate. This is not in any sense the American idea.

The Continental concept of separation is again clearly defined in the Encyclical, Humanum genus. As usual, Leo XIII first sets forth its basic principle, a monism and totalitarian absolutism of political sovereignty. Individual reason is the only authority in the realm of truth and morals. Consequently, the collective reason, represented by government, is the only authority in all that concerns both the structure of the state and the substance of society. Over the unified societystate in all its affairs, religion included, this single authority holds indisputable sway. On these grounds the society-state "separates" itself absolutely from the Church, both in the sense of rejecting her authority and in the sense of denying to her truths any foundational value for social life or any directive influence on the structures and processes of the state.

Take a look now at what the Masonic sect does in those affairs which relate to religion, especially when its licence to act is more unrestrained. Judge for yourselves whether it be not true to say that the sect wishes to give expression in social fact to the doctrines of the naturalists. A lengthy and stubbornly laborious effort is being made to see that the teaching and the authority of the Church should have no influence upon society. To this end they publicly preach and contend for the idea that sacred and civil affairs must be completely sundered. When this result is achieved, they exclude the saving virtue of the Catholic religion from the laws and from the administration of public affairs. Their consequent position is that the whole of the organized community is to be constituted quite aside from the teachings and precepts of the Church. Nor is it enough for them to pay no attention to the Church; they must wreak injury upon her by hostile action. ${ }^{24}$

(This action, the Pope goes on, seeks to undermine the foundations of the Church and to put impediments to her freedom.) The "separate" society-state is, therefore, the political transcription of philosophical naturalism. Its constitutive principles are the primacy of the political, a monism of sovereignty and of law, a conscious rejection of Christian truth and the authority of the Church, and the intention of establishing naturalism as the religion of the society-state. The Church, both

${ }^{24}$ Encyclical, Humanum genus (1884), Desclée, II, 61-62. 
as an authority and as a doctrine, is put aside in a "separate" place not only outside the legal order of the state but also outside society itself; for outside the state there can be no society. In theory the Church is somehow to disappear into exterior darkness. For the rest, the theory is that all the institutions of the closed society-state are to be animated, not by Christian principles, but by the principles of naturalism. As these principles are the "soul" of the state, so they are likewise to be the soul of all social institutions. On account of its resistance to this totalitarian ideology the Church is literally outlawed. This ideology of the "separate" society-state is again fully outlined in Immortale Dei. The same principle of totalitarianism again appears - the primacy of political sovereignty; its monism, indivisibility, and omnicompetence; its presumption both to dictate the structure of politics and to create the substance of society. The society-state based on these principles is the political transcription of the philosophia assentatrix principum, the philosophy that is sycophant of power:

When society is animated by these principles, government is nothing but the will of the people; and the people, as it is under its own single governance, alone gives orders to itself .... There is no mention of the divine sovereignty; it is as if God did not exist.... In this view, as is evident, the state is nothing but the multitude as master and ruler of itself; and since the people is said to possess within itself the source of all rights and of all power, the consequence is that the state considers itself bound by no sort of obligation toward God. ${ }^{25}$

In this conception the society-state itself becomes the divine majesty; for he who is the source of all power and rights must certainly be God. Leo XIII speaks of it as a theory of state atheism; state and society have completely separated themselves from God. The genius of the theory-its quasi-religious totalitarian character-would be better conveyed by using the later term, familiar to us today, "state idolatry." ${ }_{26}$ The theory goes beyond irreligion or indifference to religion. The society-state, autonomous and self-enclosed, is made the bearer of a new religion, a new ultimate view of man, sovereignty,

${ }^{25}$ Encyclical, Immortale Dei (1885), Desclée, II, 157.

${ }^{26}$ The term is used by Leo XIII in Au milieu (1892): "Atheism is an error so monstrous that - be it said to the honor of humanity-it can never annihilate in man the consciousness of the rights of God in order to substitute for them the idolatry of the state" (Bonne Presse, III, 121). The twentieth-century experience might lead one sadly to reflect that this is too optimistic a judgment. 
law, and society. The "man" of the philosophes himself becomes the object of his own worship. The state, which is this "man" writ large, becomes with Hobbesian literalness the mortal god. And this god makes divine claims to absolute and total sovereignty. The consequences for the Church of this idolatrous totalitarian democracy, born of a separation of man from God, are then given a statement whose exactitude can be verified by the legislative proceedings in the Continental nations which were touched by the new political religion. The point is that the Church was not really "separated" from this societystate; no totalitarian theory can admit that anything in society is "separate" from the state. The essence of the "separate" Continental state was its totalitarianism; and therefore it unified the Church with itself, making her simply an agency within the state, dependent on the civil law for her legal existence and freedom, and subordinated to the political sovereignty:

When the state is established upon such foundations as these (so much in favor in our day), one may readily see the situation into which the Church is forced, and how unjust it is. When governmental action is in harmony with these principles, the place in society accorded to the Catholic Church is on a par with, or even inferior to, the place granted to associations of quite a different nature. No account is taken of ecclesiastical laws. The Church, which must by the command of Christ teach all nations, is forbidden in the slightest way to touch public education. Civil officials on their own authority and at their own pleasure decide even those matters which are under a twofold jurisdiction [such as marriage and Church possessions]. In a word, they deal with the Church in terms of their own supposition, that she is to be deprived of the character and rights of a perfect society; they hold her to be entirely similar to all the other kinds of associations contained within the state. For this reason they maintain that all her rights and all her legitimate powers of action are possessed by her by the grant and grace of secular government .....

In this kind of political order, presently so much admired, it is a deliberate policy either to drive the Church wholly out of public existence or to hold her bound and fettered to the régime. The conduct of public affairs is in great part ruled by this intention. The laws, governmental administrative measures, the education of youth under exclusion of religion, the plundering and the destruction of religious orders, the overthrow of the civil dominion of the Roman Pontiffs - all these things look to the same end; they are designed to put an end to the vigor of Christian institutions, to fetter the freedom of the Catholic Church, and to shatter all her remaining rights. ${ }^{28}$

${ }^{27}$ Encyclical, Immorlale Dei (1885), Desclée, II, 157-58.

${ }^{28}$ Ibid., p. 158. 
The main religious consequence of the root-principle of Continental separation is that the Church too is overtaken by the process of politicization which the whole of society undergoes beneath the power of the state. This process overrides and obliterates the essential distinction between the state and Church. It also cancels the principle of the primacy of the spiritual by establishing the opposite principle of the primacy of the political. The process itself is a road to tyranny; the inevitable outcome of such totalitarianism is religious persecution. Hence Leo XIII can say: "If anywhere there exists, in reality or imagination, a state which boldly and tyrannically persecutes the Christian name, and if the new kind of polity about which we are speaking is compared with it, this new polity may appear to be more tolerable. Nevertheless, the principles on which it rests are such, as We have previously said, that no one ought to approve them on their own merits (per se ipsa).",29

The basic principle is the one on which Leo XIII constantly insists. The statement of it in Immortale Dei is simply a repetition of what he said in Humanum genus: "The source of all right and law and of all civil duties is either in the multitude or in the power which governs society - and in this power inasmuch as it is animated by the principles that have been lately come by." " ${ }_{0}$ These are the principles of naturalism. They determine the structure of the state, as monist and totalitarian. They furnish society with its new substance, a new political religion. And the new state-church, fully in the non-Christian tradition of the Continental état enseignant, undertakes to communicate its own ethical content to its citizens: "The moral instruction which is the single object of Masonic approval is that which they call 'civic morality,' 'autonomous and free morality,' that is, a morality which includes no notion of 'religion.' "'з1

It may be well to state here that only a very superficial view can situate the essence of Continental separation in the equality of all religions before the law. The doctrine of Leo XIII forbids this superficiality. Whenever he mentions this juridical equality of religions in the face of positive human law he is careful to show its relations to a much more radical theory. There is the principle that the new societystate has its own secular religion which provides it with its foundations

${ }^{29}$ Ibid., p. 164.

${ }^{30}$ Encyclical, Humanum genus (1884), Desclée, II, 66.

${ }^{31}$ Ibid., p. 64. 
apart from any appeal to the Christian religion. There is also the novum ius, the new concept of indivisible state sovereignty - a prolongation of royal and confessional absolutism - which empowers government to reduce all traditional religions to the common level of private cults, which are of concern only to the individuals who comprise them. These equal cults, insofar as they are socially organized, all share the formally appointed legal status of voluntary associations. They owe their legal existence within the society-state to the ius commune. They equally share the privileges authoritatively granted by the ius commune, with a special privilege of hostility being reserved for the Catholic Church.

It is necessary to point out here an essential distinction; my impression is that it is commonly overlooked by canonists. The First Amendment to the Constitution of the United States is not by any means the same kind of juridical provision as the Continental ius commune. The difference derives from the fundamental divergence of the political theories that are respectively the premises of each. The Continental ius commune in the "separate" society-states was predicated on the laicist prolongation of the older absolutism and regalism. Its supposition was that a power inhered in the sovereignty of the state which empowered it to formulate a statute whereby the legal status of the Church would be determined, and then to impose this statute on the Church. ${ }^{32}$ (Obviously the statute was formulated in accord with

${ }^{32}$ This notion of state sovereignty over religion appears very early in the Revolution, not as its own invention, but as part of its inheritance from the religious Caesarism of the Catholic state, so called, which preceded it. The notion that religion is an affair of state is inseparable from the notion of a religion of the state, with all that it means in the way of a bureaucratic ministry of cult, etc. Said the deputy Camus in the debate over the Civil Constitution of the Clergy in 1790: "We surely have the power to change the religion lof the state], but we shall not do so" (cf. A. Latreille, L'Eglise catholique et la Révolution française [Paris: Hachette, 1946], p. 88). The state that can establish a religion can disestablish it - such was their principle. In selecting the title, "Civil Constitution," its authors give evidence that they considered themselves to be dealing with matters quite within the customary competence of secular authority; they were the disciples of the Gallican ancien régime. Latreille well says: "What dominates the whole edifice is the statist postulate that the sovereign has the right by himself to introduce such changes as he thinks good in the field of cult" (ibid., p. 89). This statist postulate is the foundation of the Continental ius commune; it is not at all the premise of the United States First Amendment. Moreover, this statist postulate must be had in mind in reading Leo XIII's Letter to the Emperor of Brazil, E giunto (1889). It belongs to the premises of the Pope's protest against the projected changes to be made by political authority in the matter of cult. 
the "separate" society-state's own idea of religion.) In contrast, the supposition of the First Amendment is that no such power inheres in the political sovereignty as embodied in the Congress of the United States. Furthermore, the sovereignty has no such power because it was not included in the grant of power made to government by the common consent of the people. The American government is, by the act of the people which constituted it, a government of limited powers. And one of the limitations is stated in the First Amendment: "Congress shall make no law respecting an establishment of religion or prohibiting the free exercise thereof...."

The difference is clear. The Continental "separate" society-state presumed to have all power in the field of religion. The American Republic declares itself to have no power in that field. The Continental ius commune supposed that the political sovereignty, as the source of all rights, is likewise the source of whatever rights religion or the Church might have. The First Amendment supposes that the rights of religion and of the Church are primary and original; they are neither granted by the state nor may they be limited by the state. Religion is a part of the life of the Great Society, which is distinct from the state; as such, it is not under the control of the state. The only function which the people have committed to the state in regard of religion is the protection of its freedom.

Hence the manner in which the Catholic Church exists in American society is not the same as the manner of existence possessed by the Church under the Continental ius commune. In the latter case, the Church was legally free to be only what the sovereign society-state legally and authoritatively declared her to be, namely, a voluntary association owing its corporative existence to civil law. In the American case, the Church is completely free to be whatever she is. The law does not presume to make any declarations about her nature, nor does she owe her existence within society to any legal statute. In a word, the Continental ius commune denied to the Church the right to declare her own nature; the First Amendment denies to the state the right to declare the nature of the Church. The American denial was made by a whole people in a constitutional act of consent. The Continental denial was made by an ideological party in an arbitrary assertion of power. The Continental denial was conceived within the 
context of a political tradition corrupted by absolutism. The American denial was conceived within the context of the central political tradition of the West, surviving in its essential soundness. All these differences prove a radical divergence of political theories. The United States presents a political form fundamentally different from what Leo XIII was talking about. ${ }^{33}$

The Encyclical, Libertas, adds nothing but further clarity to the doctrine already set forth. The same root-principle of the "separate" society-state appears:

Once the persuasion has become fixed that no one is superior to man, it follows that the efficient cause of civil union in society is not to be sought in any principle outside of man or above him, but in the free will of individuals. It further follows that the public power finds its ultimate origin in the multitude. And it follows finally that, as the reason of the individual is the only guiding norm of action for the individual in his private life, so the reason of the collectivity must similarly be the only guiding norm of action for the collectivity in the sphere of public affairs. ${ }^{34}$

This is the familiar monist principle of political sovereignty, which is the intimate essence of the "separate" society-state. Its advocates, the Pope says, "make government a master unlimited in his powers." Or to cite a later text (and thus show the continuing emphasis on the idea), "Those who are in authority over the people claim for human

${ }^{33}$ Cardinal Ottaviani says (op. cit., II, 411): "Although the union of Church and state is singly to be approved, there is no doubt that among the forms of separation the one which obtains in the United States is better than all the others (praestare ceteris) by reason of the ample freedom granted (concessae) to the Church." The implication here seems to be that there is simply a difference of degree between American separation and other kinds, with the American system being "better," seemingly by accident. My contention is that there is a difference in kind and in principle, because the United States is in principle a different kind of polity than the Continental or Latin-American "separate" society-states with their monist, totalitarianizing tendencies. Moreover, it is not exact to say that the First Amendment "grants" freedom to the Church; this is again to interpret the American system in terms of the Continental ius commune, which is irrelevant to the American case. The American Bill of Rights does not grant rights; it guarantees them, as existent prior to, and independent of, any governmental grant. The First Amendment implies that the Church is in another order of reality - that it is a different kind of social magnitude-distinct from the state and its order of coercive law. The Church in the United States is free with her own freedom, not a freedom granted by the state. It is not, as I said, Cavour's "libera Chiesa in libero Stato."

* Encyclical, Liberlas, Desclée, III, 105. 
reason a power that knows neither measure nor law." ${ }^{35}$ If the societystate is singly the creation of the free will of man, owing nothing to nature or to God, then it is up to the free will of man alone to determine its structures and to provide it with its substance. In neither task will man look for normative guidance from religion. Society is "separate" from religion, since religion is a purely private matter, irrelevant to all that is social or political in character: ". . . the moral life of individuals ought indeed to be directed by the dictate of divine laws, but not the life of society; in public affairs it is permitted to depart from the commands of God, and to have no regard for them in the process of law-making. From this premise there follows the disastrous conclusion that society and the Church are to be dissociated.", ${ }_{36}$ Society has nothing to receive from the Church, since it generates its own principles of life; the Church has nothing to give to society, since Christian truths are socially irrelevant. Public religion is an absurdity, since religion is by definition private. Religion must be private, because by definition that which is public is created and ruled in accord with the principle, "homini antistare neminem." Man in his social and political activity has no such Sovereign Lord as religion postulates. Civil man is his own god.

This is the root-principle common to the different kinds of "Liberalism" distinguished by the Pope. Upon this principle there follows that politicization of society against which the Pope constantly protests. The Church herself is politicized: "Accordingly, they falsify the nature of this divine society; they diminish and inhibit her authority, her teaching, all her action. At the same time they aggrandize the power of civil government to the point of subjecting the Church of God to its sovereign rule, as if the Church were just another voluntary association of citizens." ${ }^{37}$ An affair of the Church is dealt with by gov-

${ }^{25}$ Allocution, Tempestivum quoddam, Desclée, III, 303. This same charge is made in Libertas against the "adherents of Liberalism" who "make government a master with unlimited powers," a sovereignty equivalently divine, because there is no other or higher sovereignty (Desclée, III, 114).

${ }^{36}$ Encyclical, Liberlas, op. cit., p. 117. Pius XI will later refer to this attitude as "moral modernism."

${ }^{37}$ Ibid., p. 118. This principle of the primacy of the political-of the new political religion and of the political power itself-is constantly cited by the Pope as the cardinal principle of the Masonic sect, which is the enemy constantly present to his thought. For 
ernment "as if it were a matter of purely civil business, entirely under the judgment and authority of the political power." 38

This monist totalitarian politicizing sovereignty is meant by the Pope in the phrase, "Eadem libertas, si in civitatibus consideretur. ..." " ${ }^{39}$ That is, it is the same absolute freedom which naturalism attributed to individual reason, only now in its political transcription. This political power, as an assertion of its primacy, assumes the power to decree that "no one cult is to be preferred to another; all are to be placed on an equal footing of right." 40 As the single ultimate source of rights, it presumes to confer upon various cults an equality of rights. And in so doing it does not even consider itself bound by any representative function in regard of the body politic: "Nor does it take any account of the people, even in the supposition that the people

instance, in the Encyclical, Inimica vis (1892), after alluding to the fact that the sect has its own substitute faith, which is to supplant the Catholic religion, he goes on: "Hence all the endless techniques for combatting the divine faith; hence the rejection and legal suppression of the rightful freedom of the Church. It is accepted as doctrine and fact that the character of a perfect society does not inhere in the Church, that civil society has the primacy, that civil government outranks the sacred power" (Bonne Presse, III, 158).

${ }^{33}$ Allocution, Tempestivum quoddam (1889), Desclée, III, 306; the reference is to the removal of a bishop by the government. The same presumption of governmental competence in ecclesiastical affairs is referred to in the Allocution, Colle espressioni (1889), Desclée, III, 299.

${ }^{39}$ Encyclical, Libertas (1888), Desclée, III, 109. The Encyclical, Pervenuti (1902), finds as the essence and "final consequence" of this freedom the principle that "man is made the proper law for man" (Bonne Presse, VII, 280).

${ }^{40}$ Loc. cit. It should be noted that Leo XIII distinguishes, though not always with complete clarity in every context, two questions. There is the theological question: Are all religions on an equal footing of right in terms of divine law? There is also the political question: Has civil government the power to decree that all cults shall be on an equal footing of right in terms of legal treatment within the society-state? An affirmative answer to the first question is heresy. But the principle of separation of Church and state lies rather in the affirmative answer to the second question, given by Continental totalitarian democracy. The answer was prompted, not simply by religious unbelief with regard to the authority of the Church, but rather by a political belief with regard to the omnipotent power of the state. This political belief in turn derived from the adoption of naturalism as the political religion of the state. These two premises give an altogether special peculiarity to laws regarding freedom of worship, in the sense of Continental separationism. Proceeding from the quasi-theological premise that naturalism is the true religion, and from the political premise that the powers of government are unlimited, the state decreed that "no one cult is to be preferred to another," since all are equal in terms of their rightsthese equal rights being possessed solely by the concession and favor of the state. This is not at all the American theory. 
profess the Catholic name." ${ }_{41}$ Bettering the instruction of the ancien régime, the civil power considers itself to be representative of a new "truth of society." It assumes the function of enforcing this truth upon all its people in all their social forms of life. It represses heresy ("les préjudices") in public life; it shows tolerance by granting equal rights of private existence to voluntary societies of dissenters from the new and true political religion. And it thus acts repressively or tolerantly in virtue of a power claimed to be inherent in the nature of political sovereignty as such.

This again is the Continental "separate" society-state, monist in its structure, totalitarian in its tendencies. And once more I remark, this is not at all, either in principle or ethos, what came to birth in the American Republic.

This description of the Continental concept of separation may be concluded by a citation from the Encyclical on the ralliement, Au milieu des sollicitudes:

We shall not use the same language on another point, concerning the principle of the separation of Church and state-which is equivalent to separating human legislation from Christian and divine legislation. We do not wish to pause here to demonstrate the full absurdity of the theory of this separation; each one by himself will understand it. From the moment that the state refuses to give to God what is God's, it refuses by necessary consequence to give to its citizens what they have a right to as men. For, like it or not, the true rights of man derive precisely from his duties to God. Whence it follows that the state, in missing under this respect the principal purpose of its institution, really winds up by denying itself and belieing what is the reason for its own existence. These higher truths are so clearly proclaimed by the voice of natural reason itself that they impose themselves on every man who is not blinded by the violence of passion.

In consequence, Catholics cannot too carefully beware of supporting such a separation. In effect, to wish that the state should be separated from the Church would by logical consequence be to wish that the Church should be reduced to the freedom of living according to the law common (droit commun) to all citizens.

${ }^{41}$ Loc. cit. This is one of the very rare texts in which Leo XIII touches on the representational character of government-a subject on which his doctrine is very incomplete. However, here he does refer to a basic medieval political principle, which was implicated in the celebrated medieval question of the deposition of kings. The king who was unjust in his laws or unchristian in his beliefs was no king at all in a Christian commonwealth, because he did not represent the people, who were Christian, and who were the depositary of the sense of justice, the norm of legislation. This was the principle which the pagan axiom, "Cuius regio, illius et religio," stood on its head, by making the people follow the prince, instead of the prince following the people. 
This situation, it is true, obtains in certain countries. It is a manner of existence which, if it offers numerous and serious disadvantages, also offers some advantages, especially when the legislator, by a happy inconsistency, does not cease to be inspired by Christian principles. These advantages, although they cannot justify the false principle of separation or authorize a defense of it, render worthy of tolerance a state of affairs which, practically speaking, is not the worst of all.

But in France, a nation Catholic by its traditions and by the present faith of the great majority of its children, the Church ought not to be put in the precarious situation which it experiences among other peoples. Catholics can so much the less extol separation in proportion as they better understand the intention of the enemies who desire it. To these enemies-and they themselves say so clearly enough - this separation means the entire independence of political legislation in the face of religious legislation. What is more, it means the absolute indifference of the power in regard of the interests of the Christian society-that is to say, the Church-and the very negation of her existence. ${ }^{42}$

What Leo XIII understands by the "principle" of separation ought by now to be clear. There is, first, the principle that the structure of the state is monist, ruled by a sovereignty conceived according to the novum ius - a sovereignty which is legibus soluta, the single author of the only law there is, totalitarian in its pretension to politicize the whole of society, religion included. Second, there is the allied principle, founded on the same ideology, that the substance of society is provided by the new "truth" about man, not by Christian truth. The power stands in the service of this new "truth"; it is completely "separate" from Christian truth and from its vehicle, the Church. Moreover, since there is a clash of truth and of authorities here, the "separate" power fights for its own truth and authority, against the Christian truth and the authority of the Church. Leo XIII thus concludes the passage cited: "They make, however, one reservation, which is thus formulated: As soon as the Church, taking advantage of the resources which the droit commun offers to the least of Frenchmen, is able to make her work prosper by a redoubling of her native activity, the state can and ought immediately to intervene and place the Catholics of France outside the droit commun itself." ${ }_{43}$

In the sentence, "From the moment...,", the Pope seems to be making the point that totalitarian democracy, inspired by its secular faith, is a self-defeating proposition. Human law, the state, and political sovereignty exist in order to create a temporal order of justice and

${ }^{12}$ Encyclical, Au milieu (1892), Bonne Presse, III, 121-22. ${ }^{43}$ Loc. cit. 
freedom - $\mathrm{a}$ reflection of the moral order-wherein citizens will be in peaceful possession of their rights, and wherein men will be able to carry out their duties to God and reach their eternal destiny. By attributing to itself the sovereignty that belongs only to God the state belies its own reason for existence. It exists for a function of ministry to man; but it assumes a function of mastery. In destroying man it destroys itself. Its political religion is not the stuff of which justice and freedom can be made. It is too airy to support even civil order, whose only stable support is the moral order sanctioned by God.

It is obvious that Catholics could not possibly consent to the principle of Continental separation, especially in view of the persecuting lengths to which the adherents of this principle were prepared to go. Nor could the Church consent to be reduced to "la liberté de vivre selon le droit commun." The reason lies in the meaning of this juridical concept as already explained, and in the whole structure and ethos of the political system in which this concept found place. Such a consent would mean infeudation to an inherently totalitarianizing regime; it would mean capture within the iron cage of a political and juridical monism; it would mean the acknowledgment that the state has the power to enfranchise the Church; it would mean a betrayal on the part of the Church of the freedom with which the Incarnate Word has made her free.

The next sentence reads: "This situation, it is true, obtains in certain countries." Perhaps Leo XIII was thinking, for instance, of Belgium. It could hardly be that the United States was in his mind. One who has a genuine understanding of the historically unique character of the American political system, and who likewise understands the concept of separation as it is evolved in the Leonine corpus, could not flatly say that this latter kind of separation obtains in the United States. There is doubtless room for criticism of the American system; but at least it is free from the two essential vices that the Pope constantly alleges as the principles of Continental separation-a monist totalitarianism of state power, and a pseudo-religious concept of the substance of society.

Moreover, it is not a "happy inconsistency" when the American legislator is inspired by Christian principles. Such an inspiration is entirely consistent with the American concept of the state and society; 
it is by no means outlawed, as in the Continental concept, by the American legal rule of separation of Church and state. This is not to say that Federal and State legislation in the United States is always obedient to such inspiration. The point is that the American legislator is under no necessity to cast himself in the role of a Continental anticlerical. American legislation does not on principle repudiate the demands of Christian morality, because, unlike the Continental "separate" society-state, it does not pretend to have an ethical and quasireligious substance of its own.

Finally, there is the question, in what sense would it be true to say that the Church in America is in a "precarious situation" in consequence of our constitutional law? The question concerns a matter of fact; it must be answered in terms of fact. On the evidence of history the fact would seem to be that the Church in America has enjoyed greater security, precisely by reason of the Constitution, than she has enjoyed in any Continental country over the same span of years. Many adjectives, some of them possibly pejorative, might characterize the situation of the Church in the United States, but hardly the adjective "precarious." The Pope rightly characterizes as "precarious" the situation created by Continental separation of Church and state. But this precariousness derives from a political hypothesis. In her Continental state of separation the Church was truly at the mercy of the totalitarianizing sovereignty of the unified society-state; hence her situation, as a power and as a people, could not be other than precarious. This, however, is not the American political hypothesis. The substantial preservation of the Christian structure of politics in the American system has contributed powerfully to make the situation of the Church not precarious but secure.

If the question is to be put in terms of precariousness vs. security, it will be impossible to make any absolute assertions. It is undeniable that the legal institution of establishment has afforded the Church a measure of security in various countries. If legal protection were withdrawn in Spain today, for instance, the situation of the Church would doubtless be quite precarious. On the other hand, there have been situations wherein this manner of legal security was joined with a great precariousness in the social situation of the Church. One might perhaps again cite the case of Spain. It was, in fact, this latter precariousness 
that enhanced the value of legal security. On the other hand, the major value of the American experience would seem to lie in its showing that the absence of legal establishment does not of itself result in a precarious situation for the Church. The decisive question is, in the name of what political tradition - what concept of the state, of sovereignty, of law, of society, indeed of man himself-is separation predicated? Continental separation was indissolubly connected with a political ideology that had broken at every fundamental point with the classic and Christian tradition. Therefore it put the Church in a precarious position; in fact, the "very negation of her existence" was entirely in the logic of the new structure and meaning of politics. On the other hand, where no such rupture with the central Western tradition has occurred, the case is profoundly different. This is the American case.

One last detail in the text of $A u$ milieu should be noted-the Pope's citation of the fact that France is a "nation Catholic by its traditions," and by the residue of social fact that history had left, the Catholic majority. This is an instance of the frequent Leonine appeal to history. History had established between France and the Church the special relation symbolized by the image, "the eldest daughter of the Church." By 1892 (Au milieu), in the circumstances of "the two Frances" created by the Revolution and by the advancing dechristianization of the masses, the image had become largely nostalgic in its connotations. Nevertheless, sacred memories clustered about it. The century-long, thrice interrupted movement toward separation had sought to shatter the image as well as the historical reality it symbolized. What God, the Master of history, had joined together, men were now striving to put asunder.

The traditional union for which the Pope here speaks, against a separation which would shatter it, was not merely or even primarily legal; the relationship of mother and daughter is not a legal relation. Not the rupture of the Concordat but the rape of the daughter was foremost in the Pope's mind. This would seem to be clear from the immediately preceding context, which deals with the question of the Concordat. The Pope states the two views in France: the extreme Left desired its abrogation, "in order to give the state full freedom to harass the Church of Christ"; the Opportunists desired its retention, "as a chain whereby to fetter the freedom of the Church." ${ }^{44}$ The Pope

${ }^{4}$ Loc. cit. 
mentions the dispute in order to warn Catholics against entrance into it; it is a "matter which belongs to the Holy See." In contrast, "We shall not use the same language on another point, concerning the principle of the separation of the Church and the state..." On this point all the faithful are to take a side-against separation.

The issue of the Concordat, which guaranteed to the Church the legal status of "the religion of the great majority of Frenchmen," was ambiguous, to say the least. In fact, the whole history of legal relationships between the Church and France had been ambiguous, since the days when Francis I set the pattern for the Union of Throne and Altar-a pattern under which the freedom of the Church had suffered grievously. In contrast, the issue of separation was not ambiguous. The real issue here was not juridical-a question of union by law established. The real issue was religious in the most profound sense- a question of union established by faith, and by fidelity to a providential history and destiny. To this union separation was an unambiguous menace. The question was, which of "the two Frances" would be France? A passage from an earlier Allocution renders the Pope's thought. After mentioning the "lovely title of 'eldest daughter of the Church," " he goes on:

She could not forget that her providential destiny has united her to the Holy See by bonds too close and too ancient for her ever to wish to break them. From that union there have come forth her true grandeurs and her most pure glories. She has continually found occasion to congratulate herself on the victories and triumphs of the Church and Papacy. To destroy the harmony of this traditional union would be to take away from the nation itself a part of its moral force and its high influence in the world. ${ }^{45}$

This is a valid appeal to history - to the bonds and union which history, under the providence of God, had created between France and the Church. The Pope is not thinking of these bonds and union in juridical terms. (What part of the grandeur of Christian France-say, in its seventeenth-century apogee - had been due to the legal arrangements of the Concordat of 1516? And was the Edict of Nantes one of the "most pure glories" of French Catholicism?) Here, as habitually, Leo XIII was contending for a union, and opposing a separation, which went far beyond anything that law could create or destroy.

In this connection the American situation appears in its most strik-

${ }^{4}$ Allocution, Nous sommes vivement (1888), Desclée, III, 55. 
ing uniqueness. In what concerns the Church-State relation there is a sense in which it is true to say that the Catholic Church in the U. S. has had no history. It has been obliged to begin a history, just as the American Republic itself began a history. In a true sense, there never was a separation of the Catholic Church from the state in America, because there never had been a historical union of the Church with the state. The term, "separation," cannot have the same meaning in the U.S. as in Continental Europe; it cannot mean in the U.S., as it did in Europe, a rupture with the past. Leo XIII could write to France in 1896 on the centenary of the baptism of Clovis (in 496, the traditional, but probably not correct date): "It can be said that the baptism of the glorious victor of Tolbiac [or was Siegebert the victor of Tolbiac, with the aid of the Salian Franks?] was at the same time the baptism of the kingdom of the Franks. ..." ${ }^{46}$ But there never was a Clovis in the history of America. There never will be one; for the age has passed when the baptism of a man can mean the baptism of a nation. This fact has consequences. The founding of the American Republic inaugurated a distinctively different political context and history. They are hardly to be compared with the contexts and histories within which the Church in Europe has been obliged to seek proper applications of her principles with regard to the Church-State relation. One can say, I think, that the Church in the U.S. can be guided only in terms of pure principle, not in terms of past applications of principle, made in alien contexts. Actually, the Church-State problem had always previously been posited in terms of the political history of Europe-in terms of the early Christian, Carolingian, and high medieval Empires; later in terms of the centralized, absolutist monarchies, of which the France of the ancien régime was the exemplar; later still in terms of the confessional absolutisms of the post-Reformation era; finally in terms of the bastard political creations of Napoleon, the Restoration monarchies, and the Revolutionary republics.

But the American Republic, as a political structure, represented a break, in different ways, with all this history. As a modern state it represented a break with the medieval imperium in all its forms-a break, that is, in what concerns the institutionalization of power, not in what concerns the essential medieval principles of politics. Again,

${ }^{46}$ Letter, C'est un noble dessein (1896), Desclée, VI, 117. 
as a new kind of modern state the American Republic represented a break with the modern state as the Continent knew it, not only in regard of the institutionalization of power but also in regard of principle. Chiefly, it broke with the unchristian principle of the one indivisible sovereignty and its unmedieval corollary, the unified society-state with its politicization and legalization of all aspects of social life.

This new political fact, the inauguration of a new history in what used expressively to be called the New World, has had consequences for the Church. Perhaps the main consequence is best indicated by the absence from the American scene of that laborious and elaborate, distinctively Continental thing known as Staatskirchenrecht, which is itself the relic of a long and special kind of history. I expect it would be very difficult for the normal American Catholic, even though he be a canonist, to regret the absence of that wondrously intricate branch of law, or to mourn the non-existence of the history which in Europe made it necessary. However, my only point here is that, if appeals to history are to be ranked as valid, the Catholic Church in America has a history to appeal to -its own distinctive history. This history has meant for the Church a new kind of spiritual experience, not tasted on the Continent - the experience of reliance on its own inner resources, under a régime of constitutional law that has been equitable (as the droit commun of Revolutionary Europe was not), but not creative of legal privilege (as the various régimes of establishment were).

This experience requires evaluation in its own context, which is not the context of modern Continental political history. American constitutionalism broke with that history, for excellent reasons; there is neither the intention nor even the possibility of returning to it. The United States, as a new political and social phenomenon, will go on making its own history, for good and ill. The Church in the United States is engaged in that history, for good and ill, just as the Church in France, for good and ill, was engaged in the very different, but likewise unique, and somewhat ambiguous history of France, and of the other so-called Catholic nations of Europe. Hence a question rises. Is the Church in America to be allowed to travel her own historical path and fashion her own particular solution to the Church-State problem, remaining faithful to essential Catholic principle, but likewise striving for effective application of principle to the specific character 
of the political tradition within which her institutional life is lived? Or, on the other hand, is the Church in America to repudiate the history of America in what is most unique about it-its installation of a political tradition sharply in contrast with that of modern Continental Europe? Is she to be bound to those special applications of principle which were necessary and legitimate within political contexts alien to her own?

The wisdom of St. Thomas teaches that a political system and its whole structure of law (including the laws - or in St. Thomas' day, the customs - in which the Church-State relation finds expression) are the work of nature in the full Roman and Christian sense. They are therefore to some extent a product of historical forces and experience; they are not created by naked reason or by sheer Christian principle. (The Church did not create feudal Europe, or the national state; least of all did she create the ancien régime.) It was the folly of the philosophes to suppose that the state is simply a work of art in whose construction history can be denied, custom abolished, social experience disregarded, and the lines of the structure altered at the mere command of the rational will, to conform to the exigences of abstract ideas.

Leo XIII therefore was on sound ground in appealing to the history of France against the heirs of the philosophes. By the same token one would be on sound ground in appealing to the history of the United States against any who would somehow repeat the error of the philosophes in the name of juridical essences. Three hundred years of American history - about as long as the span of the ancien régimehave firmly established a political tradition. The structure left by these centuries can indeed be improved and the tradition itself purified; but neither can be abolished. The history of the United States will never "repeat" that of Continental Europe. The Church in America will never "repeat" her historical situation in the so-called Catholic nations. This is a fact, with consequences.

In this connection one must ask, of what relevance to the American case is the notion of a "Catholic majority"? Obviously, as used by Leo XIII in the context cited, the notion was entirely relevant, for the simple reason that it was not an abstraction, not a statistical notion. It was a reality that formed an essential part of his appeal to history. The Catholic majority in France was a residue of history. It was not a 
numerical sum of individuals, an aggregate, a formless crowd. It was the historical reality of "the old France," in present conflict with the "new France." Moreover, this "old France" came out of the past bearing with it not simply the Catholic faith as such, but a particular national heritage, compounded of multiple national traditions. It represented-to use a familiar distinction-not simply l'Eglise catholique which France had long honored, but le monde chrétien which France had long been. Therefore this determinate French Catholic majority could be made the premise of a valid argument.

Basically, the argument was for the old faith; but it was also for the old France. Both were under attack by the newly concocted secular faith and by the newly organized "separate" state (the Third Republic was really "separate" from the Church long before the juridical act of 1905). Leo XIII was prepared to defend both the old France as well as the old faith, the "Christian world" of France as well as the Catholic Church in France. (Up, that is, to a point; there came a time when he was no longer willing to sponsor what had been a part of the French monde chrétien for so long that many Frenchmen had come to think of it as an integral part of the Catholic Church-namely, the monarchy.) In arguing from the historical reality of a Catholic majority, the Pope was arguing for the particular "Christian world" which had been, as it were, the "form" of that existent entity. He was arguing from history, not from statistics. He was arguing for history, not for an abstraction, a juridical essence.

What was, in point of religious and social fact, this Catholic majority? To answer the question, one must recall that the "Christian world" which was France (or the other so-called Catholic nations) was not the pure creation of the Catholic faith as such; it was the result of a juncture between Christianity and a particular political culture. It had two characteristics. First, the construction of this particular Christian world had been chiefly the work of great kings. Second, the dominant experience of the Catholic majority had been the experience of tutelage by Christian princes. This was even more emphatically true after the enforcement in the post-Reformation world of the "pagan principle," cuius regio, eius et religio. It is not likely

${ }^{47}$ So it rightly styled by J. Lortz, Die Reformation als religiöses Anliegen heute (Trier: Paulinus-Verlag, 1948), p. 202. Assent must be given to Lortz's brief but balanced, and 
that anyone will contest these assertions on the ground of historical fact. The Christian world of the so-called Catholic nation bore the mark of Clovis, and Recared, and especially of Charlemagne, who revived a pagan tradition, as he revived the Roman Empire, by assuming the function of episcopus externus, charged with the construction and administration of the Church, i.e., the Christian world. The Catholic majority in this Christian world likewise bore an ancient stamp. It was in effect the army of Clovis, three thousand strong, following their chieftain - the "new Constantine," as Gregory of Tours called him - to the baptistery and under the obedience of Bishop Remigius. ${ }^{48}$ The relation of Clovis and his national Church, especially as later given something of form in a sort of Concordat between the Church and royal power at the Council of Orléans in 511, was a prefiguration of the Union of Throne and Altar that became characteristic of the later Christian world of the Catholic nation, as it issued from the crack-up of Christendom. All the value is there, and all the ambiguity too. ${ }^{49}$

The point is that the Christian world, characteristic of the Catholic

not wholly favorable, judgment on the use of the secular arm as the external characteristic of the Counter-Reform. The best that can be said is that the Church operated then "with the methods customary at the time" (loc. cil.), however alien they were to her own spiritual nature.

48 "... it is in France that medieval kingship most quickly and completely realized its design [which was-the author has just said-that of personifying the country, concentrating all powers in the hands of the King, and rejecting any limitations on his 'good pleasure']: an axis lying in an almost straight line leads to this end, from the baptism of Clovis to the vigorous and jealous autocracy of Louis XI, passing through the Carolingian rite of anointing, the moral dictatorship of virtue under St. Louis, the enlightened despotism of Charles V, the tyranny of gentleness of Charles VII" (J. Calmette, L'Elaboration du monde moderne [Paris: Presses Universitaires de France, 1949], p. 320).

49 The ambiguity consisted, of course, in the admixture of religion and politics. Clovis' own conversion was in part politically motivated. His politics included a politique religieuse, a Kirchen politik (perhaps significantly, there is no proper English translation of that typical Continental thing). In the convocation and conduct of the Council of Orléans Clovis acted in true Constantinian fashion; cf. Hefele-Leclercq, Histoire des Conciles, II, 2 (Paris: Letouzey, 1908), 1006, note 2. On the circumstances of Clovis' conversion, cf. Fliche-Martin, Histoire de l'Eglise, IV (Paris: Bloud et Gay, 1937), 394-96. On the similar pattern set by the Gothic kings of Spain, cf. Essays on Church and State by Lord Acton, ed. Douglas Woodruff (London: Hollis and Carter, 1952), pp. 386-87. It was as early as Recared that "the preservation of religious unity became a political principle," "that the principle of religious unity was first made a law of the State," in the interests of national conquest and consolidation (ibid., p. 387). 
nation, bore these identifying marks upon it in consequence of the circumstances of a particular political culture. ${ }^{50}$ That a multitude should be in the image, more or less close, of Clovis' army is not a per se proposition, part of a thesis; it is an historically contingent fact, a hypothesis. Given the fact, religio-political tutelage - after the fashion of Clovis, or Louis XI, or Garcia Moreno, it does not matter-properly follows as an adaptation to the fact. The Church was pleased to make the adaptation. But this kind of tutelage does not on that account become itself a per se proposition, a thesis.

It seems to be clear that Leo XIII considered the Clovis-army concept of a Catholic majority to be still a social fact in his own day. France was still the "baptized nation"-which is not a theological concept or a juridical one. The "old France" which he had to defend was the France which still stood in need of the kind of tutelage to which it had been accustomed in the historical monde chretien from which it came. Whatever may be said about Leo XIII's ideals, and per se propositions, and theses, it cannot be forgotten that he was an unremitting realist. As I shall say later, he knew the conditions of religious and political culture that prevailed in the old France, the old Spain, - the old Austro-Hungary, the old Italy, the old Bavaria. To him the Catholic majority was not, I repeat, a statistical notion. It was the "ignorant multitude" (multitudo imperita), , $^{\text {s1 }}$ which is the factual premise of an important part of the theory of government found in Libertas. As I shall also say later, Leo XIII bent every effort to alter

${ }^{50} \mathrm{On}$ the effects of state-religion on the people in the "Catholic world" of confessional absolutism, during the Reformation era, there are interesting data in Karl Eder, Geschichte der Kirche im Zeitalter des konfessionellen Absolutismus (Wien: Herder, 1949). For instance: "The preservation of the Catholic religion and the reconstruction of the Church went on so essentially from the top down, that the people came more and more to be considered as the natural and God-given workshop for governmental edicts. This had two different consequences. The centralization of rule significantly increased, and it considerably facilitated the measures for recatholicization. On the other hand, in the eyes of the people religion and the Church came increasingly to appear as an affair for the government. People remained Catholic or became Catholic because so the prince ordained, and his functionaries supervised one's fidelity. But the thing by no means happened as a matter of personal conviction" (ibid., p. 7). Later he remarks: "The turning of the Catholic Church from the people to the prince was one of the most fateful consequences of religious division, in spite of the momentary advantages it brought" (p. 16). Leo XIII, despite his preoccupation with princes, was the first Pope to reverse this centuries-long movement; in him the Church turned from the princes to the people.

${ }^{51}$ Encyclical, Libertas, Desclée, III, 110. 
this deplorable social and religious fact. In the meantime he saw his Catholic majority - the old Catholic nations, the old Christian worldmenaced by the contrefaçon of Clovis, a new kind of "external bishop," showing traditional favor towards an untraditional thing-a new political religion. ${ }^{52}$ This was the factual situation which the Pope faced. He faced it with complete realism, as his paternal concept of government shows. This topic will return later.

But what sense does this notion, a Catholic majority, make in the American case? There is no such residue of history in the United States; there is no "old America" to be defended or restored. The notion becomes merely statistical, and therefore meaningless. It offers no kind of premise for argument, such as it offered in Leo XIII's text. In using it one is at best talking in terms of futuribles - and non-pure futuribles at that, as far as any human foresight can go. Even if it should prove to be a pure futurible, what warrant is there for prophesying that an American Catholic majority would reveal the lineaments of the historical majorities in the so-called Catholic nations as described by Leo XIII? Would it be ignorant, religiously apathetic, socially inert, a mass of "subjects," standing in need of tutelage by some Clovis-like power in a regime that would be a repetition of the old monde chrétien? Does anyone know what a "Christian world" would be like that is not fashioned by great kings but by a genuine Christian people, whose historical experience has not been of subjection to the power and tutelage by it, but of active participation in the power and control of it? Can anyone describe the spiritual reality of a Catholic majority that would be the historical product of an American future and not a relic from a European past? And if one cannot describe this spiritual reality, one cannot argue from it-not, that is, and remain faithful to the concrete Leonine manner of argument.

This notion of a Catholic majority has been victimized by what Gabriel Marcel stigmatizes as "the spirit of abstraction." It has been

${ }^{52}$ Cf. Encyclical, Depuis le jour (1899): "We are not unaware of the fact that the enemies of the faith are not in a state of inactivity, that they have succeeded in banishing all religious principle from a great number of families, who consequently live in a lamentable ignorance of revealed truth and in a complete indifference towards everything that concerns their spiritual interests and the salvation of their souls" (Bonne Presse, VI, 94). This is one of the texts in which Leo XIII gives his concrete understanding of the Catholic majority, now under antireligious governmental tutelage as formerly it had been under religious tutelage by government. 
stripped of the existential reality which it has in the argument of Leo XIII. He was not arguing from numbers but from history, and from the determinate sociological reality, with distinctive spiritual and cultural characteristics, which had been the heritage of history, the product of the juncture of Christian faith with the facts of a particular political culture within the so-called Catholic nations. If you change these facts - as the United States has changed them, largely by validating the proposition that government is to be by the people, and is to be limited in its powers-you will supposedly change your historical product. Certainly, the present American Catholic minority is not the predominantly peasant and proletarian Catholic population of the old Catholic nation, so called. They have the same faith, but they are not the same kind of people, because their history has been different. The futurible majority which might grow from them will not be the Catholic majority of Leo XIII's argument. His argument was valid because his premise was real. But it is unreal to equate an actual Catholic majority, residual from a particular segment of history and a special kind of political culture, with a futurible Catholic majority prophesied as eventual in a new segment of history and a different political culture.

\section{Conclusion}

The purpose of this article so far has been to explore what exactly it was that Leo XIII condemned when he condemned separation of Church and state. If I understand his doctrine correctly, the conclusion is that, after full assent has been given to this condemnation as a matter of Catholic duty, there is still room for an unprejudiced examination of the American concept of separation, because this latter concept is different in point of political principle from the concept condemned. The inquiry into the American concept should not be clouded by a confusion of it with the distinctly different Continental concept, which was born of a fundamentally divergent political tradition. American separation requires examination on its own principles, its own intentions, its own merits and defects.

It should be already clear that American separation may enter a valid plea of "not guilty" on the two basic counts in the papal indictment of Continental separation. The first count in the indictment bore upon the social and juridical monism that was the immediate premise of 
Continental separation. The consequences for the Church of this monism of societies, law, and sovereignty were such as to make it radically incompatible with basic Catholic doctrine. The separation predicated on this monism shattered the traditional structure of politics and put an end in principle to the freedom of the Church. However, American separation is not based on any such monist theory. The traditional structure of politics is preserved by the distinction between society and state. The consequences for the Church are quite different from the consequences of Continental separation. Notably, the freedom of the Church is not destroyed, but guaranteed.

The second count in the papal indictment bore upon the social apostasy inherent in Continental separation. This apostasy consisted in the conscious repudiation of the Christian and rational truths which tradition asserted to be foundational to the union of men in societyto the "coniunctio societatis humanae," in Leo's phrase. The apostasy also consisted in the attempt to substitute a new political religiona new truth, a new law, a new concept of social man-as the ethical substance of society. Furthermore, the civil power undertook the protection and propagation of this new political religion, this new secular ecclesiology, as it might well be called. However, American separation has no such pseudo-religious meaning or consequences. It does not entail the exile of God or of the Church from American society. It does not mean the enlistment of the civil power in the service of a political religion. It does not involve a social apostasy. In a word, the "separate state" of the American formula is not in any recognizable sense the "separate society-state" of the Continental formula. More simply, the American "state" is not the Continental "state"; this is the root of difference.

The American system can therefore validate its plea of "not guilty" with regard to the two basic charges in the indictment of Continental separation. This fact is of considerable importance. However, the inquiry has to be carried further. Leo XIII not only described and condemned the Continental concept of separation; he also outlined, in opposition to it, a concept of christianitas. The term is here used, and will hereafter be used, with its medieval connotation of a certain solidarity, amid all proper distinctions, of the sacred and the secular, the spiritual and the temporal orders of human social life. The Leonine 
development of the concept of Christianity-in certain respects a new development - was the obverse, positive side of his condemnation of Continental separation. It remains therefore to examine this concept. One will thereafter be in a better position to determine the status of the American system in the face of Catholic doctrine. Or, what is more important, one will be in a better position to state the full Catholic doctrine on the relation of the Church to state and to society, as conceived by Leo XIII.

\section{THE LEONINE CONCEPT OF CHRISTIANITY}

Leo XIII set forth his concept of Christianity in the course of developing two great themes. The first theme is the Christian structure of politics, as over against the separationist structure and its juridical and social monism. This theme deals with the problem of Church and state. The second theme is the Christian substance of society, as over against the political religion of laicism. This theme deals with the problem of the Church and society-a broader problem than that of Church and state. A principal part of the historical significance of Leo XIII, in the history of the development of doctrine, lay in his distinction of these two problems, and in the emphasis he laid upon the latter. This latter theme may also be called that of the social necessity and value of religion. It is a metapolitical and metajuridical theme.

\section{The Christian Structure of Politics}

Leo XIII's statement of the Christian structure of politics is contained in the seven major texts in which he gave a newly refined statement to the central tradition whose first classic enunciation was made by Gelasius I. The Leonine statement, like the Gelasian, is properly theological, not juridical. The propositions contained in these texts are antecedent to any statements that may be made about formally legal arrangements between Church and state. They are superior to, and regulative of, the whole problem of the concrete institutionalization of the Church-State relation. They contain the absolute and final truth, in that mode of generality which alone can make the statement of the truth absolute and final, independent of historical contingencies, valid for the year 53 as for the year 1953 .

A positive exposé of what Leo XIII meant by Christianity ought to 
begin with these texts. Treatises on public ecclesiastical law frequently follow a more apologetic pattern. The question of separation of Church and state is treated antecedently to the question of what is called their union. The first step is the exposition of errors - state atheism, indifferentism, separationism. The essence of separation is conceived in juridical terms; separation is made a legal concept. After the refutation of errors in the matter, the true doctrine is sometimes presented as a deduction from the refutation of these errors. So, for instance, by Cardinal Ottaviani: "Since all these things [state atheism, etc.] are erroneous and pernicious, one can properly deduce that some positive system of juridical relations ought to exist, whereby the necessary relation (colligatio) between the two powers may be established." ${ }_{53}$ The argument is that, since the essence of separation-the wrong, disorderly relation-is legal, therefore the essence of the right, orderly relation must likewise be legal. There must be a legal "union" of Church and state, through the incorporation of the Church into the legal structure of the state, i.e., the national state, usually conceived by the canonists as a society-state.

It is not my intention to criticize this fairly common apologetic method of approach. One may, however, doubt whether it is always safe thus to back into the truth, so to speak, on the rebound from error. Continental separation was indeed to some extent a matter of legal act; it involved the rupture of legal bonds that had previously existed between Church and state. Whether the proper essence of Continental separation was therefore legal or juridical is a proposition that I would myself question, in the light of Leo XIII's doctrine in the matter. The idea of legal disestablishment played an extremely minor role-if any role at all-in his lengthy and minute description of separation. In any event, there is a problem in the consequence of the argument. Because Continental separation involved injurious legal action on the part of totalitarianizing political sovereignties, does it therefore follow that the essential exigencies of Catholic principles on the Church-State relation are satisfied only by a "union" also legally effected? The consequence here is not luminously clear. If legal union, in the sense of an establishment of Catholicism as the religion of the state, is to be zsserted as the only right and orderly relation, this legal concept of

${ }^{53}$ A. Ottaviani, op. cit., II, 103. 
establishment ought to be derived directly from a scrutiny of positive principles - the origin, nature, and functions of political power as such; the distinct origin, nature, and functions of the sacred authority as such; the fact that they rule over the same man, who is Christian and citizen, a member of two societies; and the consequence of this fact, that there must be a harmony and an orderly cooperative relation between the two powers and the two societies. Whether a process of dialectical argument, under no appeal to history, will lead from these principles to the concept of legal establishment seems to me doubtful. It will be as unsuccessful as an attempt to conclude to a jurisdiction of the Church over the temporal power as such from the premise that the end of the spiritual society and power is in a higher order of reality than the end of the temporal society and power. This theological and political premise does not yield such a juridical conclusion.

Actually, the apologetic approach contributes to the avoidance of a fundamental problem. Is a system of formally juridical relations a deduction from essential principles, or is it the product of history - the consequence of the special kind of legalization that public order has undergone, in Continental Europe, notably after the reception of Roman law, at the hand of the developing modern sovereign state, in consequence of which the Church, in order to obtain any place in national public order, had to obtain a legal place, and hence had to legalize her relation to the state? If this second alternative be true (as I think it is), it will, of course, leave untouched the validity of this juridical system in its own context; but it will set the system itself in a different light by showing it to be a historical development in the application of principles rather than a nakedly dialectical deduction from the principles themselves. ${ }^{54}$

\footnotetext{
${ }^{54}$ The simple question, which might perhaps best illumine the matter, would be this: What would have been the prevailing concept of an orderly Church-State relation, if Roman law had never been received on the Continent, if the passage from feudalism and the Empire to the nation-state had been accomplished in France-to take the leading instance-in the same way in which it was accomplished in England, if the distinction between society and state had not disappeared under the pressure of political absolutism? These developments were not the result of a divine imperative; they were historical contingencies. They created a public order of a special modality. The formalization of the Church-State relation in terms of legal concepts and institutions corresponded to this modality. In that fact these concepts and institutions found their legitimacy and merit. But the modality of public order might have been other than it was. In America it is
} 
Moreover, in this view of the matter one will be in a better position to understand the high medieval situation, wherein there was, properly speaking, no system of formally juridical relations between the two powers, such as the modern era introduced. These may have been the "ages of perfect agreement" (foederis perfecti), as Cardinal Ottaviani calls them..$^{55}$ One could easily exaggerate the perfection of the medieval situation; in any event, to speak of an era of "perfect agreement" fails to indicate the peculiarity of the situation-the religio-political conception of the Church as the one Great Society with two administrative hierarchies; this was not a piece of perfection but of immaturity, proper to a particular stage of civilizational development. Moreover, to speak simply of "perfect agreement" leaves in the air the nature of the agreement; it has a distinct modality, hardly comparable with what obtained under the ancien régime.

A more serious difficulty is that this apologetic approach results in a certain distortion of Leo XIII's doctrinal edifice. To put the juridical problem (legal establishment vs. non-establishment) in the foreground is to alter the perspectives of the Pope and to shift emphasis to an aspect of the matter that was not primary with him. The Leonine notions of "ordinata colligatio" and "concordia" are not in the first instance juridical notions. If it is permitted to deal in abstractions, one can readily conceive a polity in which there would be an ordinatissima colligatio between Church and state without any sort of system of juridical relations. One can indeed arrive at the notion of legal relation from the notion of orderly relation, but not by a process of immediate deduction. There is need of a middle term, which only history can supply, in the form of a particular kind of political society, produced by the forces of history, which required the formal legalization of the Church-State relation in virtue of a particular concept of

other than it has been on the Continent during the modern era. There are a multitude of other provocative historical "ifs": if the Arians had never reached Gaul and the Iberian peninsula; if there had never been a Constantine, a Clovis, a Recared, a Charlemagneand therefore no Gregory VII to fight for the freedom of the Church against the enslaving customs of the Frankish and Gothic kingdoms; and if no Hildebrand, no Innocent III; if too there had been no Philip the Fair, no civilians created at Bologna, no Louis XI.... And so on. Has all this history, which might have been other than it was, made no difference? Does the history of the United States, which is so different from the history of Europe, make no difference? What difference does it make?

${ }^{55}$ Op. cit., II, 104. 
the structure of public order. It is the special merit of Leo XIII that in formulating the tradition in his Gelasian texts he went beyond history and gave his statements a generality that makes them-unlike the legal concept of state-religion-transhistorical, purely doctrinal. ${ }^{56}$

From a theological point of view, therefore, and also in the interests of a more correctly accented presentation of Leo XIII's doctrine, it is preferable to begin an exposition of the Leonine concept of Christianity where he himself began it-not with a refutation of errors but with a statement of the truth, the central tradition regarding the structure of society. This tradition is contained in the seven Gelasian texts in his corpus. They state the two irreducible data, rational and revealed-the origin, nature, and function of civil society, and the distinct and superior origin, nature, and function of the Church. They also state the immediate and necessary implications of these data in what concerns the relation of Church and state, as these implications result from simple analysis, without any recourse to historical middle terms. Thus one comes closest to a statement of the tradition in its pure form.

It is true that the Leonine statement of tradition, like the original Gelasian text, was uttered in particular historical context. Hence it reveals the accent which the Holy See judged necessary to meet the needs of that context. This accent falls on the freedom of the Church. ${ }^{57}$ However, although Leo XIII chose this locus of accent for immediately historical reasons, he actually chose the locus which the genuine tradition itself demands as the proper locus.

Another accent is possible on what medieval writers called the

${ }^{58}$ In suggesting that the legal institution of a state-religion in the Continental sense is not the pure product of principle but also the product of history, I am not at all implying that it is illegitimate, that it does not square with Catholic doctrine, that it ought to be abolished, or anything of the kind. Much less am I attacking or deprecating any existent situation - such as obtains in Spain, for instance. The point here, as elsewhere in my writings, has simply been to understand and explain this legal institution of establishment. I think that an essential part of the understanding and explanation must be in terms of historical contingencies - the circumstances of particular political contexts and cultures, national traditions, etc. When the institution is thus explained, it is not therefore invalidated-quite the contrary; an essential part of its validity consists precisely in its adaptation to these circumstances.

${ }^{57}$ Of the hundred or more texts in which the formula, "libertas Ecclesiae," recurs (or an equivalent formula), perhaps one-fourth have to do with the Roman Question. One providential result of this tragic impasse was that it drew the Church's attention to this central thing-her freedom. 
"unity of the Church," meaning the role of the prince in the edification of the Church and in the construction of a Christian world. But this is an accent inherently proper to the regalist or civilian tradition. A major significance of Leo XIII in the history of doctrinal development lies in his great effort to rescue the Church from the regalist tradition - from that servitude to the state under which it had lain for nearly half a millenium of regalism. The servitude dated from the triumph of Philip the Fair's lawyers over Boniface VIII, which had been solidified by the rising centralized national monarchies, especially in France. In a full view, Leo XIII appears as the Gregory VII of the nineteenth century, returning under the stress of the times to the splendid device under which the great Hildebrand fought his battle, "the freedom of the Church." 58

Perhaps the simplest thing now will be to give the major Gelasian texts, together with several other illustrative ones, reserving a brief comment until the end. The first text occurs toward the end of the Encyclical, Arcamum (January 8, 1880); it gives the general theory of the structure of society which supports the previous discussion of the respective functions of state and Church in regard of Christian matrimony:

There is no doubt that Jesus Christ, the founder of the Church, willed that the sacred power should be distinct from the civil power and that each should be free and untrammeled in the conduct of its own affairs. In addition, however, as a matter of their mutual advantage and the general good, a harmonious relationship should exist between them. The power to which the affairs of men are entrusted should at the proper juncture wait upon the word of the power which has in its charge the affairs of heaven, in such matters as are, in different ways, under the common jurisdiction and judgment of both. The best interests of both powers depend upon this manner of harmonious arrangement; it likewise offers the most suitable and effective means of assisting mankind in all things which pertain to the conduct of this life and to the hope of eternal salvation.

We have in previous Encyclicals made the point that human intelligence, when it is in accord with Christian faith, is greatly ennobled, and more fully empowered to avoid and resist error, while in its turn faith derives considerable assistance from

58 "In moments of considered solemnity, when their tone was passionate and their religious feeling at its deepest, Gregory VII and his contemporaries called the object towards which they were striving the 'freedom' of the Church" (G. Tellenbach, Church, State, and Christian Society at the Time of the Investiture Contest, transl. by R. F. Bennett [Oxford: Blackwell, 1940], p. 126). So too Leo XIII: "Right from the beginning of our pontificate... we formed the resolve to make every effort to restore by all possible means the tranquility of peace together with a rightful freedom for the Catholic name" (AAS [1887], 465). 
intelligence. In similar fashion when civil authority is on terms of friendship with the sacred power of the Church, the advantage is necessarily great on both sides. The dignity of the civil power is increased and under the guidance of religion its rule will never be unjust; on the other hand the sacred power is furnished with the assistance of a protection and a defense unto the public good of the faithful.

These were the considerations which on previous occasions moved us to exhort men in authority to harmony and friendship; we now again strongly repeat these exhortations. With fatherly kindness we took the initiative in reaching them the hand of friendship. We offered them the assistance of our supreme power, which is all the more necessary in these days in proportion as the right of rule has suffered damage and has increasingly lost its hold upon the minds of men. An insolent spirit of liberty has inflamed the minds of men; an impious attempt is being made to throw off the yoke of all rule, however lawful. In this situation the public welfare demands that the resources of both powers should be united in order to ward off the evils which threaten not only the Church but even civil society itself. ${ }^{59}$

The second text is found in the Encyclical, Nobilissima Gallorum gens (February 8,1884), on the Christian government of domestic and civil society; it again states the essential principles governing the structure of politics - the two powers, the two societies, and their harmonious relationship:

We come now to those most salutary truths which regard civil society and the reciprocal rights and duties of the sacred and the political powers. There are upon earth two great societies. One is civil; its proximate end is to insure the temporal and earthly good of mankind. The other is religious; its function is to lead men to the true blessedness for which we are made, an eternal blessedness in heaven. In like fashion there are two powers. Both of them are subject to the eternal and natural law, and each of them, in matters which fall within its own respective order and jurisdiction, looks to its own interests. However, when decisions are to be made in areas in which both powers, for different reasons and in a different manner, are competent to make decisions, a harmony between the two is necessary, in consonance with the demands of the public welfare. The absence of this harmony will inevitably bring about an ambiguous and unstable situation, inconsistent with the peace both of the Church and of civil society. When therefore a settlement at law has been publicly reached by the sacred and civil powers, and ratified by covenant, it is a matter of the public interest, as well as of justice, that full harmony should prevail. The fact is that, when each performs its duties in regard of the other, a clear profit accrues to both sides from the exchange. ${ }^{60}$

What is in some ways the leading Gelasian text occurs, naturally enough, in the Encyclical, Immortale Dei (November 1, 1885), on the Christian organization and structure of civil society. The Pope con-

${ }^{55}$ Desclée, I, 137-38.

${ }^{60} \mathrm{Ibid}$., II, 47-48. 
fronts the "new opinions on civil society" with Christian doctrine. The first point is the origin of civil society from God through nature, with emphasis - after the Leonine habit - on the divine origin of the civil power. After an interruption in the flow of thought-a section on "public religion," against the protagonists of the new political religion - the argument turns to the foundation of the Church by Christ. The basic conclusion concerning the structure of politics is the following:

Although this society, quite like civil society, is made up of men, nevertheless it is supernatural and spiritual by reason of the purpose of its institution and by reason of the means whereby it pursues its purpose. On this account it is distinct and different from civil society. What is of the highest importance, it is a society perfect in its kind and by its own right, since it possesses in itself and by itself, through the will and grant of its Founder, all the resources necessary for its well being and its action. As the end to which the Church tends is by far the most sublime, so its authority is primatial. It cannot be considered inferior to civil government or in any way subject to it. ${ }^{61}$

From these fundamental premises the Christian doctrine on the structure of politics follows:

Accordingly God has divided the government of the human race between two powers, the ecclesiastical and the civil. One of them is set in charge of divine things, the other of human things. Each of them is supreme in its own order; both of them are confined within certain limits, set by their respective nature and purpose. Hence there is a certain defined area in which each may act by native right. However, both powers rule over the same men, and occasions arise in which one and the same matter, in diverse ways, falls under the jurisdiction and judgment of both. In His providence, therefore, God, by whom both powers were established, had to mark out a course of action for each in right relation to the other. "For all authorities that hold sway are of His ordinance." Otherwise disastrous disputes and conflicts would frequently arise, and the individual man would often be troubled, and hesitate, like a traveller at a crossroads, uneasy about his course of action, when the two powers, neither of whose commands he can in conscience reject, issue contrary injunctions. Accordingly it is necessary that a certain orderly relationship should obtain between the two powers; not without reason has this relationship been compared to that by which soul and body in man are joined. What this relationship should be, and how far it should extend, can only be judged, as we have said, by reflecting on the nature of both powers. Regard must also be had of the excellence and nobility of their respective purposes, since the first and chiefest aim of one is to provide a sufficiency of earthly things, and of the other, to put heavenly and eternal goods at the disposal of man. Consequently, whatever

${ }^{61}$ Ibid., pp. 150-51. 
is in any way sacred in human affairs, whatever has relation to the salvation of souls or to the worship of God-whether it be such by its own nature, or regarded as such by reason of the purpose to which it is referred-stands under the authority and judgment of the Church. As for those other things which are ranged in the category of civil and political matters, it is right that they should be under the control of the civil authority, since Jesus Christ gave command that the things which are Caesar's are to be rendered unto Caesar, and that the things which are God's, unto God.

Moreover, there are times when another manner of harmony is valuable in the interests of peace and freedom. It consists in a settlement reached by agreement between rulers of states and the Roman Pontiff concerning particular matters. At such times the Church gives signal proof of maternal love, inasmuch as she is accustomed to display the fullest possible measure of ready tolerance. ${ }^{62}$

\section{One further brief text from Immortale Dei may be added, to illus- trate the accent on the freedom of the Church:}

In similar fashion it is to be understood that the Church, no less than the civil community, is a society perfect in its kind and by its statute. Those who hold the high power of government ought not to perpetrate the wrong involved in forcing the Church to serve them or be subordinate to them, in allowing her less than her proper freedom to conduct her own affairs, or in taking away any part of the other rights conferred upon her by Jesus Christ. In affairs over which jurisdiction is shared the thing which is in accord with nature and likewise in accord with the plan of God is not a schism between one power and the other, much less strife between them, but rather a harmony - such a harmony as will be consistent with the immediate causes which brought both societies into being. ${ }^{63}$

A resounding text occurs in the Letter, Officio sanctissimo (December 22,1887 ), to the Bavarian episcopate, on the general situation in that country. There is a heavy accent on the freedom of the Church:

Among the goods of the Church, which we must everywhere and always preserve and defend against every injury, this surely is the most excellent, that the Church should enjoy that measure of freedom of action which is required by her care for the salvation of men. This is a divine freedom, derived from the onlybegotten Son of God, its author, who raised up the Church by the shedding of His Blood, and willed to be Himself its Head. This freedom is so much the property of the Church, as a perfect and divine work, that those who act against this freedom likewise act against God and against their duty.

As We have elsewhere more than once said, God established the Church in order that she might have under her care and attention and at her disposal those ultimate 62 Ibid., pp. 152-53.

${ }^{63}$ Ibid., p. 161. 
goods of the soul which are of incalculably greater value than anything found in nature; and also in order that through the resources of faith and grace she might bring to men from Christ the new life which makes for eternal salvation. Now both the nature and the empowerments of any society are chiefly marked out by the causes from which it derives its existence and by the purposes towards which it directs its action. From this principle certain consequences readily follow.

It follows that the Church is a society distinct from civil society, by a distinction that follows the differences between their immediate causes and purposes. It follows that the Church is a necessary society, which reaches out to the whole human race, since all men are called to the Christian life, in such wise that those who refuse [the Church] or abandon [her] are sent away forever and have no share in the life of heaven. It follows above all that the Church is a society in her own right and is the most excellent society by reason of the excellence of the heavenly and immortal goods that are the object of her whole striving.

Now then, it is evident that causes that are free carry with them the free faculty of employing whatever means are to their purposes. In the case of the Church, these are the things - the instruments, as it were-that are fitting and necessary: that she should on her own judgment teach Christian doctrine, administer the sacraments, perform divine worship, establish and regulate the whole discipline of the clergy. God wishes that the Church should be endowed with these beneficent functions, and in His providence He wills that she alone should be endowed with them. He committed to her, as in a treasury, all the things which He had of His own inspiration spoken to men. He established her as the single interpreter, judge, and mistress of truth, wise and most certain, whose precepts are to be listened to and followed by individuals and by civil societies alike. He likewise made it clear that a free mandate had been given by Him to the Church to make such judgments and decisions as would more effectively further His own purposes.

Wherefore it is without reason that civil governments cherish suspicions of, or take umbrage at, the freedom of the Church, since in the last analysis both the civil and the sacred power have the same source in God alone. Consequently, they cannot be at cross purposes, or block one another, or cancel one another out, since God cannot be inconsistent with Himself, nor can His works be in conflict among themselves; indeed their characteristic is a marvelous harmony of causes and consequences.

It is further evident that, when the Catholic Church in obedience to the command of her Author carries her standard widely and freely among the peoples, she is not making sorties into the territory of the civil power, or acting in a manner prejudicial to its interests. Rather, her function is one of protection and defense. The comparison here is with what happens in the case of Christian faith. So far from blocking off the lights of human reason, faith adds luster to reason, inasmuch as it turns reason aside from the errors of opinion to which it is humanly prone, and admits it to higher or more spacious realms of intelligible reality. ${ }^{64}$

M Ibid., III, 33-35. 
The Encyclical, Sapientiae christianae (January 10, 1890), contains a pointed development of the theme, which emphasizes the dynamic religious purpose of the Christian structure:

Both the Church and civil society have their own proper sovereignties; and for this reason neither of them obeys the other in conducting its own affairs within the limits set by the immediate cause of each. However, it does not therefore follow that they are to be sundered, much less that they should be in conflict. It is the intention of nature that we should not simply be, but also be moral. Hence man makes this demand upon the tranquility of public order which is the proximate purpose of the organized civil community, that it should allow him to be a moral being, and, what is more, that it should furnish him with sufficient assistance towards the perfection of his moral nature-a perfection that consists in knowledge and the exercise of virtue. But at the same time man wants, as he must want, to find in the Church the means whereby he may fulfill his perfect duty of perfect piety - a duty which lies in the knowledge and practice of the true religion which is the primary virtue inasmuch as it recalls us to God and thus sets a finishing crown on all virtues.

Consequently, in establishing institutions and laws regard must be had of man's moral and religious nature and its perfection must be in view. But right order is here to be observed; nothing is to be commanded or forbidden except in the light of the respective purposes of the civil society and of the religious society. For this reason, the sort of laws that obtain in society are necessarily a matter of concern to the Church, not to the extent that they are within the right of the civil power, but because at times they go beyond proper limits and encroach upon the statute of the Church.

Furthermore it is the duty of the Church, given to it by God, to resist whenever the system of public order is detrimental to religion, and to make zealous endeavors to have the influence of the Gospel permeate the laws and the social habits of the people. And since the fortunes of the commonwealth chiefly depend on the quality of the men who are in authority over the people, therefore the Church cannot give endorsement or favor to those men who are known to be hostile to it, who openly refuse to respect its rights, who strive violently to rend asunder civil affairs and sacred affairs, which are by nature associated. On the contrary, the Church is, as it must be, patroness of those who hold such views of the civil community and of the Christian community as it is right to hold, and who are willing to fashion a harmony between them in what concerns the common good. ${ }^{65}$

For the rest, on a true judgment in the matter, supernatural love of the Church and natural love of country are twin-born loves, proceeding from the same eternal source, since God is author of both. From this it follows that neither duty can conflict with the other. We can and indeed we must do two things: on the one hand, we must love ourselves, be kind to our neighbor, love the commonwealth and the

${ }^{65}$ A AS , XXII (1890), 397. 
power which has authority over the commonwealth; on the other hand, we must cherish the Church as a mother and honor God with the fullest possible love.

Nevertheless, the order of these duties is at times perverted in consequence either of the disorders of the times or of the unjust will of men. That is to say, cases arise in which the civil community seems to demand one thing of its citizens and the Christian religion demands something else. The reason is that the governors of civil communities either care nothing for the sacred authority of the Church or wish it to be subjected to themselves. Hence, conflict arises, and the conflict is the occasion of danger to virtue. Two powers press their claims, and they cannot both be obeyed, because they command contrary things: "no one can serve two masters." The result is that if one is obeyed, the other must be disregarded. But which of the two is to win preference in the case is not open to doubt. ${ }^{66}$

Given this delimitation of rights and duties, it is entirely clear that the governors of the civil community are free to conduct their own affairs. The Church is not reluctant that they should do so; on the contrary, she lends them her aid. Her chief precept is that piety, which is justice towards God, should be cultivated; and by the same token she summons men to justice towards their governors.

However, in virtue of a far more lofty ordinance the sacred power looks to the governance of men's souls under regard for the kingdom of God and his justice. This is her whole concern. But it cannot be doubted, without injury to faith, that this governance of souls is committed to the Church alone, in such wise that the political power has no part at all in it; for it was not to Caesar but to Peter that Jesus Christ entrusted the keys to the kingdom of heaven. ${ }^{67}$

The Encyclical, Praeclara gratulationis (June 20, 1894), was the first world-wide address of Leo XIII. It was directed "to all rulers and peoples," and it urged them to unity in faith, in order that religious, social, and political peace might at last be assured. After speaking at length to non-Catholic peoples, the Pope turns to the Catholic world. He states again, with the usual emphasis, the central tradition on the structure of politics, and makes a comment on the current situation:

Since [the Church] is, as we have said, a perfect society, it has by divine ordinance a principle and power of life inherent in its own nature, not derived from any source outside itself. For the same reason, the Church has the native power to make laws; and in their making it is right that she should be subordinate to no one. Likewise in other matters which are under her own jurisdiction the Church must be free.

However, her freedom is not of a kind that could awake rivalry or jealousy. For the Church does not seek political power (potentiam), nor is she motivated by selfish ambition. Her one wish, her single desire is to further among men the practice of virtue, and in this way to see to their eternal salvation. Consequently it is her wont to show a ready spirit of maternal kindness. Indeed it happens not seldom

${ }^{66}$ Tbid., p. 387.

${ }^{67}$ Ibid., p. 396. 
that she makes generous concessions to political circumstance and refrains from the exercise of her rights - a fact to which abundant testimony is given by many agreements reached with governments. Nothing is more alien to her than to usurp the rights of government. But conversely, government ought to respect the rights of the Church, and be at pains not to transfer to itself any part of them.

But if you look at the facts of the situation today, what is the movement of the times? Surely you see that altogether too many people have accustomed themselves to hold the Church in suspicion, to dislike her, hate her, and bitterly criticize her. What is much more serious, they are making full use of all their energies in order to make her the servant of state sovereignty. Therefore her property is being confiscated, and a curb is being set upon her freedom. Therefore the training of candidates for holy orders is being beset with difficulties; extraordinarily severe laws are being passed against the clergy; religious communities, those strong supports of the Christian enterprise, are being dissolved and banned. In a word, the principles and procedures of the regalists are being put into newly harsh effect.

All this means that violence is being done to the sacred rights of the Church. By the same token great evils for the city itself are being prepared, given the fact that this course of action is in open conflict with the divine plan. For God, the creator and ruler of the world, has providentially set both the civil and the sacred power over the human community. He has indeed willed that they should remain distinct; but $\mathrm{He}$ has forbidden that they should be separated (seiunctas) and brought into conflict. Furthermore, the common good of human society as well as the will of God firmly demands that civil power in its rule and governance should be in harmony with the ecclesiastical power. Government has its own rights and duties; so too has the Church. But government must be related (colligatum) to the Church by a bond of harmony.

So it would come about that the mutual relationships of Church and government would disentangle themselves from their present disorder, reckless as it is on more than one count, and ruinous in every direction. At the same time, another happy result would be obtained: with the affairs of Church and government neither confused, one with the other, nor sundered, one from the other, citizens could render to Caesar the things that are Caesar's and to God the things that are God's. ${ }^{68}$

The final major text is in the Encyclical, Pervenuti (March 19, 1902), in which the aged Pontiff surveys his reign and the current state of affairs. He returns once more to his cardinal point on the architecture of organized human life:

They say that the Church usurps the rights of the state and invades the political field. But the Church knows and teaches that her divine founder commanded men to render to Caesar the things that are Caesar's and unto God the things that are God's. And in this fashion he sanctioned the immutable and perpetual distinction

${ }^{68}$ Ibid., XXVI (1894), 712-13. 
of the two powers, both of them supreme in their respective orders. It is a fruitful distinction which has had a large part in the development of Christian civilization.

In her spirit of charity the Church rejects as incongruous with herself all hostile aims. Her purpose is simply to range herself at the side of the political powers. ${ }^{69}$ She does indeed exert her influence on the same subject, which is man, and on the same society, but by such channels and with such lofty aims as are at the height of her divine mission. Where her efforts are welcomed without suspicion, they succeed only in increasing the innumerable benefits mentioned above. The imputation of ambitious designs is nothing but an ancient calumny of which her powerful enemies make use as a pretext to justify their oppressions. History, studied without prejudice, amply testifies to the fact that the Church, so far from attempting an abuse of power, has in fact often been the victim of such abuse and injustice. In this she is the image of her divine founder. And the reason is that her power consists in the force of ideas and truth and not in the force of arms. ${ }^{70}$

The foregoing texts give the cachet to Leo XIII's doctrinal work. There is nothing comparable to them in the previous literature of the nineteenth-century controversy as carried on by his predecessors. The severity of the challenge put by totalitarian democracy, which went to the very bedrock of principle, compelled a statement of principle which would be properly ultimate. It will be noted, as I said above, that Leo XIII recurs to primal data and states the resultant principles in their full generality and therefore in their universality, undiminished by any admixture of the historical. These texts contain the irreducible essence of the Catholic doctrine on the Church-State relation. The principles stated are of the theological order and of the order of elementary political philosophy. The concepts are not juridical. In fact, in two of the texts the Pope is careful to distinguish the reduction of the Church-State relation to a juridical system, established by Concordat, from his definition of the relation itself in terms of general principles. A lengthy commentary on these texts might be in order, but here it will be matter simply of pointing out the cardinal emphases.

The major emphasis falls on the distinction between Church and state. This is the most prominent aspect of their relation, that it is a relation between two societies distinct in origin, purpose, and means for achieving purposes. The Leonine statement is the clearest and

${ }^{69}$ The official French text has "... à marcher parallèlement aux pouvoirs publiques"; the official Italian text has: ". . a coordinarsi a fianco dei poteri politici." There was no Latin text.

${ }^{70} A A S$, XXXIV (1902), 526. 
most formal one ever made by any Pope on the fact that there are two societies and not merely two powers. This was a significant development over the medieval concept of christianitas - the concept of the one Great Society within whose unity only the two powers were distinct. As I have elsewhere tried to show, the after-image of the medieval situation hung on for centuries; it was the somewhat concealed premise which gave to Bellarmine's elaboration of the indirect-power theory its unclear, ambiguous character, as really a direct power confined to exceptional use. ${ }^{71}$ Leo XIII's recognition that civil society is a proper society in its own right, and not simply an order of life within the Church, dissipated the medieval after-image, and invalidated for modern times the special peculiarity of medieval Christianity, the unitary concept of society. Actual conditions of political fact and right made this development necessary.

This clear distinction of the two societies prepared the way for Leo XIII's new emphasis on the transcendence of the Church to civil society and to all manner of political forms. This emphasis in turn led to an insistence, visible in a host of texts, on the purely spiritual character of the Church's purpose, ministry, and means of ministry. Furthermore, the broader problem emerged. It is now a question of the Church's relation to the whole of temporal society, in all its range of institutions, and not merely a question of the relation between her supreme authority and the civil power as such. Thus Leo XIII furnished the starting-point for the developments undertaken by Pius $\mathrm{XI}$. In the latter's doctrine the whole Church-not only her authorities but notably her laity - is to be engaged in establishing right relations between the Church and society, meaning the whole institutional life of society, not merely the political organs of government.

The emphasis on the distinction of the two societies and on the transcendence of the Church had another consequence. It established more clearly than ever before the autonomy of political society and of its government in the sphere proper to them. In particular, the problem of political forms and processes of government is definitely handed over to reason and political experience, which are the proper dynamisms of political society. In the text of LeoXIII this rejection of any alliance

\footnotetext{
${ }^{n}$ Cf. "St. Robert Bellarmine on the Indirect Power," Theological Studirs, IX (1948), $499 \mathrm{ff}$.
} 
between the Church and a form of government had a special reference. It was based on a recognition, perhaps somewhat belated, of the fact to which de Tocqueville had pointed generations before in speaking of France: "The living body of religion has been bound down to the dead corpse of superannuated polity; cut the bonds which restrain it, and that which is alive will rise once more." ${ }^{\prime 2}$ The Union of Throne and Altar had bred a damaging alliance of the Church with a political institution - and later with a social class, the capitalist bourgeoisie, to which the Restoration monarchies were enfeoffed. Leo XIII sought to break this union. However, although his doctrine had this special reference, it was based on principle - the correlative principles of the transcendence of the Church and the autonomy of political society and its forms. It is a question whether these principles, so firmly laid down, have yet worked themselves out in all their implications. It is particularly a question whether these implications are obeyed when the Church within a particular national society is linked with government through its incorporation into the legal structure of the state. It has to be remembered that every legal structure rests upon, and is shaped by, an underlying political form. I say, "the Church within a particular national society"; for the matter of a legal bond, established by Concordat, between the Holy See as a supranational authority and a particular national government is something quite different; it does not incorporate the Church within a particular state as part of its special legal structure. Concordats imply no participation in, or approval of, political forms of government.

In any event, Leo XIII was the relentless enemy of all confusion $J$ between religion and politics, all involvement of the Church's transtemporal interests with the fluctuating fortunes of historical forms. One text, among many, must here be given. It is addressed to Spain. After rejecting the error of separation in the Continental sense, the Pope goes on:

But as this wicked error is to be avoided, so also the reverse opinion is likewise to be shunned-the opinion of those who mix up religion and partisan politics and make of them a confused unity, even to the point of declaring that men of another party are unfaithful to the Catholic name. This is to push political factions into the holy field of religion; it is deliberately to rupture fraternal harmony, and open

${ }^{72}$ A. de Tocqueville, Democracy in America (New York: Barnes, s.d.), I, 343. 
the way to a disastrous amount of harm. The sacred and the civil, which are by nature distinct, ought to be dissociated in one's thinking. Considered in itself, the order of civil affairs, for all its value and seriousness, does not in any sense go beyond the confines of this earthly life. On the contrary, religion, which looks to God and refers all things to God, has a higher scope; it extends to heaven. Its aim is to imbue with the knowledge and love of God the noblest part of man, his soul; its intention is safely to lead the whole human race to the City which is to come, which we are now seeking. The right thing therefore is to consider religion, and whatever is related to religion by some special bond, to be of a higher order. Consequently, being the highest good, it must remain intact amid the flux of human affairs and amid all political changes; for it spans all time and space, uninterruptedly. ${ }^{73}$

This doctrine may raise a difficulty against the political and legal institution of a religion of the state in the sense of Continental law. The fact of the matter is that this legal status cannot be obtained save by an alliance of a national Church with a political party and by her embrace of a particular political form of government. To take an instance, Catholicism is the religion of the state in Spain today only because the form of the Spanish state is dictatorial, and only because the Spanish Church is allied, more or less deeply, with the "party" of the dictator. It may be said that those who favor both the dictatorship and the privileged legal status of the Church are "the real nation," whereas those who do not are "not of the nation." But this sort of Catholic Jacobinism, which would assert that only Catholics are "the people," whereas those who are not Catholics are "not of the people," is a dubious proposition. The constitutional concept of a religion of the state is not indeed invalidated by this difficulty. Like any other concrete institutionalization of the Church-State relation, this one has its merits and also its defects, since it represents an accommodation to exigencies of social fact and political tradition. Such accommodations are constantly made by the Church in view of some good to be achieved. But the difficulty militates against the erection of this situation into an ideal. An ideal situation ought to fulfill to perfection all the exigences of every principle in the matter, including the principle upon which Leo XIII laid such stress - the Church's independence of political forms and factions.

Linked with the notion of the autonomy of the state in its forms and processes is the other notion which Leo XIII emphasized-that the

${ }^{73}$ Encyclical, Cum multa (1882), Desclée, I, 317-18. 
purpose of the state is not the salvation of souls, the guidance of men to their eternal destiny. It would be an "injury to faith," says Sapientiae christianae, to deny that "the governance of souls (regimen animorum) is committed to the Church alone, in such wise that the political power has no part in it at all." Or in the blunt words of Immortale Dei, "Man's guide to heaven is the Church, not the state." This firm doctrine puts an end in principle to all manner of religious Caesarism, which has had a long history in the so-called Catholic nations. The doctrine likewise puts an end in principle to all theories and practices of a curialist tinge, which would enlist the civil power as an instrument of the Church, endowed with a part in her governance of souls. When Leo XIII is thinking in terms of pure principle, derived from original data, he sharply limits the state to secular purposespurposes that lie within the horizons of this world. (The number, nature, and importance of these purposes become clear when the Pope enlarges on the functions of the civil power toward the solution of the Social Question, which is a question of this world-a matter of achieving that measure of balance between freedom and justice which is possible in this world.)

The value of the state is its value for this life. The civil power is not a sort of Spiritual Father. Its purposes are political. This firmly stated principle is relevant to the question, later to be discussed, of political cura religionis. The principle sets a definite limit: whenever this cura religionis becomes a regimen animorum it contravenes principle: "Istiusmodi regimen animorum Ecclesiae esse assignatum uni, nihil ut in eo sit politicae potestati loci." When the Pope says "no part at all," it is to be presumed that he means "no part at all." Not even therefore an instrumental part. Consequently, when one finds in history the civil power playing a part in the governance of souls, one can be sure that other factors were at work beyond the exigences of principle; they were factors inherent in special historical circumstances.

This aspect of Leo XIII's doctrine is a warning against speaking inconsiderately of rights or duties of the state to ward off spiritual dangers to the supernatural faith of its citizens. This function would certainly seem to pertain to the governance of souls. Again, there is the opinion which would entrust to the civil power the preservation of the unity in Catholic faith of a particular national society. One 
might ask, in what sense is this supernatural unity a res huius saeculi, and in what sense is its preservation a secular, political purpose, which would in principle fall within the competence of the civil power? That the unity of the nation or the state is a political purpose may be granted. But that the religious unity of a people may be made a means to the political unity of a nation or a state is an indefensible proposition in the light of Leonine doctrine. These considerations are not condemnations of various practices of so-called Catholic governments in the past or present. ${ }^{74}$ One can possibly legitimize these practices. The concrete workings of any particular form of the Church-State relation always reveal, to a greater or less extent, infringements of principle, concessions to expediency, some manner of compromise. The Church has always understood this. But objection can be raised when these ambiguous situations are consecrated as "ideal," and when departures from principle, made necessary by circumstances, are asserted to be verifications of principle. The important thing is that the principles which Leo XIII lays down as irreducible should be given their full value, and that accommodations of principle to exigencies of political or cultural fact should be recognized for what they are.

The second major accent of Leo XIII is consonant with, and consequent upon, the first. In fact, it falls on the same principle, the freedom of the Church, but now with another connotation. The freedom of the Church follows from her transcendence as a spiritual and supernatural society in her own right, possessing a purely spiritual authority, which she does not in any way share with the civil power, and which she exercises on her own cognizance, independently of the civil power. This is the freedom of the Church from the state-from subordination to its power and purposes, and from involvement in its autonomous processes and forms. This freedom is the denial of any attempt to enclose the Church within the state as part of its structure. But from the same premises there follows the freedom of the Church in another more positive sense. This is the freedom of the Church to enter, by her

\footnotetext{
"With the exception of the Spanish Inquisition. This religio-political institution cannot be defended in the light of Leo XIII's developed doctrine. It can only be historically explained-up to a point. Its popularity at the time was a factor. Like the Revocation of the Edict of Nantes, the action of the Spanish Inquisition enjoyed a large measure of approval by the people. It remains to know whether the people approved it for the right reasons-for reasons compatible with Christian charity.
} 
proper spiritual action, the area of temporal affairs. It is the denial of the attempt made by the Continental "separate" society-states to shut the Church completely out of their self-enclosed unity, within which one sovereign power ruled indivisibly over everything. This is the freedom of the Church in the general sense of its greatest protagonist, Gregory VII. It is likewise the freedom over which the sharpest controversies have raged. Its theory and practice have seen unconscionable exaggerations (in the curialist tradition of the canonists, who almost brought St. Robert Bellarmine to grief when he curbed their exaggerations), and equally unconscionable diminutions (in the civilian tradition of the royal lawyers, and in the laicist tradition formally launched by Marsilius of Padua and perfected by the Jacobins and their heirs).

This freedom is sometimes called the indirect power of the Church in temporal affairs. It is difficult to see what theology would lose by the exile from our technical vocabulary of that ambiguous term, which nobody seems able to define to the satisfaction of everybody else. ${ }^{75}$ Leo XIII never used the term-advisedly, one must think. But he gave new precision to the doctrine which it attempts rather clumsily to express. One could best call it the doctrine of the primacy of the spiritual. The Leonine development is beautifully clear and simple. It contains two basic assertions. There is, first, the doctrine of the

75 "Various people explain in various ways how this power is indirect. Some call it indirect because it is exercised on a distinct, though related, power; others call the power indirect because it pertains to the Church, not inasmuch as these things are temporal, but inasmuch as they have a relation to something spiritual; others call the power indirect because the civil power, whether private or especially public, is subordinated to the Church in the use of temporal goods not of itself (ratione sui) or by reason of its own end, but by reason of something else, namely, the end which the Church pursues. Others distinguish between temporal acts and merely spiritual acts concerning temporal things-the idea is that the Church can make dispositions concerning temporal things only by spiritual acts (excommunication, for instance), and in this way indirectly make dispositions concerning temporal things; but she cannot perform temporal acts, sc. by directly commanding a temporal action or affair (for instance, the cessation of an action or a law). Finally, others abandon the terms, "direct" and "indirect" power, and simply assert that a power in temporal things belongs to the Church insofar as the end of the Church requires it" (R.-M. Schultes, O.P., De ecclesia catholica, ed. Prantner [Paris: Lethielleux, 1931], p. 353). There are problems of doctrine and of history here involved; but they are needlessly complicated by the baffling term, "indirect" power. The lucidity of Leo XIII's doctrine commends itself: that the authority of the Church is a sacred authority, in its nature and in all its acts, and its object is always a res sacra, at times in temporalibus. 
res sacra in temporalibus: in the temporal life of man there are elements of the sacred. There is, second, the doctrine of the necessary freedom of the Church to reach, as it were, into the temporal order and lay authoritative hand upon the sacred elements therein contained. In using the phrase, "primacy of the spiritual," two assertions are therefore made. First, not all the things contained within the temporal order of human life are of equal rank. There is a hierarchy among these things: some are sacred, some are secular, some are both sacred and secular under different aspects. The second assertion is that the authority of the Church, being of the sacred order, extends, as Immortale Dei puts it, "[to] whatever is in any way sacred in human affairs, whatever has relation to the salvation of souls or to the worship of God, whether it be such by its own nature or regarded as such by reason of the purpose to which it is referred." Correlatively, the power of the state, being of the profane order, extends only to the profaneusing "profane" in the classical sense of what is "outside" the order of the sacred. It is an essential attribute of the freedom of the Church that she should liberate the sacred from any profanation at the hands of the state. She accomplishes this work of freedom by asserting her own exclusive authority over whatever is sacred.

The special characteristic of the Leonine doctrine derives from its premise-his emphatic doctrine of the authority of the Church as purely spiritual, in sharp distinction from the power of the state, which is purely profane or infrasacred, if you will. Because the authority of the Church is entirely of the sacred order, therefore it extends only to the sacred-but to everything that is sacred. And the sacred is found not only in the sacristy, as the totalitarian democrats would have had it, but also in the world, in hoc saeculo. On the other hand, the Church has no temporal power-no profane or political power. Nor has she any power "over the state," or "over the civil power"; for the state and its power are, as such, of the profane order, and the Church's authority is only over the sacred.

This doctrine of the primacy of the spiritual was strongly directed against the New Regalism of the totalitarian democracies; it hit too at the old regalism of the so-called Catholic states. Both had asserted the primacy of the political - the latter, in certain respects, the former, absolutely. But the doctrine itself, although it had a polemic bearing, 
represented an analysis of essential principle clearer than any previously made. Here too Leo XIII developed the tradition by clarifying it. The development was in the line set by Bellarmine against the canonists, but it went beyond Bellarmine. Bellarmine's central ideaas it was the central idea of the tradition itself-was the purely spiritual character of the Church's authority; but he did not fully follow out all the implications of the idea. The after-image of the medieval onesociety theory, the still dominant "direct-power" doctrine, as well as his own polemical preoccupations, interfered. His "indirect power" becomes on occasion a political power, capable of producing juridical effects within the political order as such. The concept may be regarded as a valid adaptation of principle to a historical context in which the political order was simply an order within the Church, the one society. Leo XIII, by shattering this framework of the question, was able to, and did, draw out the full implications of the central tradition. In his doctrine the term, "indirect power," would have no particular meaning. To him the power of the Church is always direct, because always purely spiritual; it always goes directly to the res sacra -the sacred in itself, and the sacred in the temporal.

If Leo XIII's doctrine is looked at as a whole, it will appear that there was for him ultimately only one res sacra in temporalibus, namely, Christian man himself. His thesis on the freedom of the Church is intimately and consciously related to the central thesis of Christian anthropology. There are sacred elements in the temporal order because there are sacred elements in Christian man. There is his intellectual nature, which endows him with a freedom beyond the reach of the power whose competence is bounded by the horizons of the terrestrial world. There is the grace of Christ, which endows him with a still higher freedom - a participation in the freedom of the Church, which is itself, as Leo XIII says, a participation in the freedom of the Incarnate Word. The Church sets her spiritual authority in the service of these two freedoms of man. The enemy is a power, or a theory of the state, which would assert that in the political order everything is political, and subject to the political power; which would reject the idea of the res sacra in temporalibus; which would therefore deny that there is anything sacred in man himself; which would, in final consequence, make of man a purely political animal, whose freedom is merely of the 
political order, characterized by the precariousness which is the mark of all things political. A glance at the texts already cited - and there are many others-will show how firmly Leo XIII sets in the center of his Church-State doctrine the true concept of Christian man and his freedom. The totalitarian state can never destroy the Church; but it does destroy men and their freedom. Perhaps Leo XIII did not see this truth as clearly as later generations have seen it; but he certainly glimpsed it. Hence his emphasis on the ultimate bulwark of the freedom of man and society. This bulwark is not offered by parchment declarations of the rights of man, however useful they may be. It consists in the living reality of the freedom of the Church.

Scattered throughout the Leonine corpus is a rather full articulation of what is meant in detail by the res sacra in temporalibus. The following are the chief items, merely stated: the husband-wife relationship, the parent-child relationship (including education), the political obligation, the human dignity of the worker, the equality of men as all equally in the image of God, the moral values inherent in economic life, the works of charity and justice which are the native expression of the human and Christian spirit, the patrimony of ideas which are the foundation of human society - the ideas of law, freedom, justice, property, moral obligation, civic obedience, legitimate rule, etc., etc. There is also the thing, sacred in its destination, whereby the Church occupies ground in this world, namely, her legitimate property. But the chiefly sacred thing in the temporal order, in Leo's eyes, is the inner unity, integrity, and peace of man, who is both Christian and citizen. The notion recurs constantly. It is, so to speak, the earthly pivot of the Leonine doctrine of concordia.

If sheer repetition of the word means anything, one must say that Leo XIII's overwhelming emphasis was on concordia -harmony between the two powers, harmony between the two societies. The word strikes literally the keynote of his pontificate. It is also the summation of his doctrine on the Church-State relation, as a look at the inner structure of the concept will reveal.

First of all, the notion is not a legal notion. Leo XIII distinguishes the principle of concordia itself from its special legal expression in a Concordat. Moreover, his two favorite analogies are devoid of juridical connotations. The relation between body and soul is not juridical, nor 
is the relation between faith and reason. He never uses the ancient analogy of the sun and moon-an analogy freighted with suggestions of the direct-power theory. Nor does he ever use the still more famous metaphor which held fairly damaging sway over canonical theory for centuries - the evangelical metaphor of the "two swords." Its connotations were of the medieval one-society theory, papal delegation of the temporal power, the instrumentality of the secular "sword" in regard of the Church's purposes, a jurisdiction on the part of the Church over the civil power as such, etc. The omission of these ancient analogies corresponds to the rejection of the pseudo-traditions, or the "received ideas," if you prefer, of which they once were the vehicle. The relations of body and soul, and of faith and reason, more successfully convey the intimate nature of the Church-State relation as it is to be described in terms of the exigences of principle, antecedent to any practical demands of concrete situations which might, or might not, result in the reduction of principle to some form of legal expression-Concordats, constitutional laws providing for the legal status of the Church in society, statutory provisions concerning particular matters, etc.

The body-soul analogy is defective in that Church and state do not coalesce into a substantial unity. The faith-reason analogy is defective in that the two powers do not inhere in a single subject. But both analogies remain valid. Like the relation of body and soul, and faith and reason, the Church-State relation is spiritual, dynamic, purposeful, reciprocal, and orderly. The essential point of comparison is that it involves a cooperation between two distinct principles, of unequal dignity in nature, each of which operates quod suum est, under the primacy of the higher principle, towards an end which is common to both, but under different aspects.

For Leo XIII harmony between Church and state is initially demanded by the common origin, in different ways, of the two powers and two societies from God. This is a central traditional idea. There was agreement on it among the three currents of thought in the medieval period. The partisans of imperial - and later of royalsupremacy, the partisans of papal supremacy, and the middle party, more attentive both to experience and to essential principle, which contended for the distinction of powers and their orderly relation-all these three orientations had one common point of agreement. It lay 
in the firm belief that the whole structure of human existence ought to be organized by the transcendent sovereignty of God, of which - in different ways, according to the different theories-both the authority of the Church and the civil power were earthly representatives. (The clash of views concerned only the respective parts to be played by these two powers in establishing right order in the world.)

Leo XIII emphasizes this traditional root-principle of harmony, and the correlative principle of right order. But, whereas the medieval theorists thought more naturally of right order within the one society which was the Church, Leo XIII, in the light of the developed doctrine of the two societies, thinks of right order within the one man, who is a member of two societies and subject to the laws of both. This is clear from the texts cited. It might be noted that he is not for this reason an individualist in the bad sense, as if his "one man, Christian and citizen" were the atomistic individual of rationalist theory. He is thinking in terms of man's nature, as not only personal but also social - and social in two directions, inasmuch as Christian man is a "civil," and also an "ecclesiastical," man. Pius XI will complete this doctrine by his institutional theory of society and by his insistence that the reform of society - the harmonization of the Church and society - can only be achieved by institutional action.

Both the origin and the finality of the two powers and societies require that they act in harmony with each other. The harmony itself consists, in fact, in the orderliness of their cooperation. The first principle in this order of cooperation is that the freedom of the Church, in the twofold sense explained, should be accorded full respect by the secular power which rules the earthly society. This outlaws all social and juridical monism, and all regalism. It outlaws all profanation of the res sacra supra temporalia which is the Church herself (her authority, doctrine, social form) by her inclusion within the order of civil society, which is inferior in dignity and end. It further outlaws all profanation of the res sacra in temporalibus by its total subsumption under the control of the power whose concerns can only be secular.

The second principle of orderly cooperation is that the freedom of the secular power, and the autonomy of the forms and processes of the political order, should be fully respected by the Church. Much more than his predecessors, Pius IX and Gregory XVI, Leo XIII shows on 
every possible occasion an anxious concern for this freedom of the state and its governmental processes. He rejects in principle all clericalism - understanding by the term all theories and practices which misconceive the autonomous nature of the state and misuse its power. The misconception and misuse would lie in the reduction of the state to the level of a mere means, whereas it is in itself an end, although only an intermediate end. This is a misconception because it violates the distinction of Church and state, which is a distinction in orders of reality that are related indeed, but still radically discontinuous, as nature and grace are discontinuous. Between the lower and higher order there is an absolute disproportion, in such wise that the things and the methods of the lower order cannot properly be means to the ends of the higher order. The clericalism which would make secular government simply an instrument of the Church is an error.

Clericalism can involve an undervaluation of the political order-a denial, for instance, that it can be the milieu of natural human ideals, such as the ideals inherent in what can be called, though not in a Jacobin sense, the "democratic faith." Clericalism more often involves an overvaluation of the political order-the attribution to it, for instance, of functions of salvation which are out of proportion to its nature, beyond the legitimate scope of the means and powers at its disposal. There is a clericalism which would make civil society over into the image of the Church, or into the image of the family, or possibly into the image of a tight little convent boarding-school, into which no breath of "the world" should blow. Against all these forms of clericalism Leo XIII would protest in the name of order-in the name of the legitimate freedom of civil society to be simply civil, not ecclesiastical, society. The affairs of this earth, which are the content of civil society, have their own value. In fact, the value that they have in themselves is the necessary premise of any value that they may have for man's higher end, eternal life, with which the Church concerns itself. The first freedom of civil society is a freedom to be good according to its own distinct nature, as a civil society.

The harmony of the two powers and of the two societies, as conceived in principle by Leo XIII, is a dynamic harmony. It is harmony in the order of action, a harmony of operations. It is, in a word, an 
orderly cooperation. Two things result from the texts quoted. First, the Church has an office of protection and defence in regard of society and government. It is part of the duty of the Church to further by her own proper mode of action the ends of both state and society, because these are human ends which apart from the spiritual aid of the Church - her doctrine, law, and authority-cannot be properly achieved. Reciprocally, society and government have an office of protection and defence in regard of the Church. It is part of the duty of government and of all the institutions of society to further by their own proper mode of action the end of the Church, which is the supreme human end, the achievement by men of the ultimate human purpose, salvation. Leo XIII, in the ensemble of his doctrine, takes this matter of dynamic harmony or orderly cooperation between the two powers and the two societies in its broadest, most true dimensions. This enlargement of the question is part of his originality, an important aspect of the development of doctrine operated by him.

This whole subject will be left for later discussion. Included in the subject is the question of governmental cura religionis - a relatively minor matter in the perspectives of Leo XIII. The inquiry into this matter involves a prior study of the two concepts of government and the state, and their relation to society, which are to be found in Leo XIII. There is the strictly legal and political concept which appears in Rerum novarum and in other texts which deal with the functions of political power in relation to the economic order of society. There is also the paternal, rather than political or legal, concept of government which appears in the texts that deal with the relation of political power to the religious and cultural order of society. The fact that the Pope proposes two concepts of government-different in modality, different too in what concerns the limitation of governmental power-creates something of a difficulty.

This study of the reciprocal mutual cooperation of the two powers and the two societies will complete Leo's doctrine of what I have called the structure of politics - a structure that is dynamic, a cooperative harmony of the two powers and two societies. It will also move into the other aspect of his doctrine, on what I have called the substance of society. This is the point of doctrine that was the theme 
of his first Encyclical, Inscrutabili, a theme endlessly orchestrated in the ensuing long line of documents: " $\ldots$ the doctrine of Christ, if it be hearkened to, is the great salvation of society." 76

Cognate to this doctrine is another theme - what he calls "public religion," that is, man's duty to honor and worship God publicly. This last theme occasions no theological difficulty. The social nature of man creates an obligation of social worship. The fact that human society is by nature politically organized imposes an obligation on the representatives of political society towards this social worship - towards the fostering of it and toward participation in it. The institution of the Church specifies the forms in which this social obligation of religion should be exercised - the forms of Catholic faith and worship. These propositions present no doctrinal difficulty, although there was great polemic difficulty over them in consequence of the rationalist concept of religion as a purely private matter and the Jacobin concept of public religion as political in character and substance. In practice the question solves itself, when a society is genuinely religious; official acts of public worship and faith naturally become part of its mores. Theoretical difficulties can only arise if the question of social worship and societal profession of faith is confused with another question, distinct from it, namely, the legal question of establishment - the legalization of Catholicism as the religion of the state, as this legal institution was known in the historic Catholic nations, so called, of the modern era in Continental Europe.

A future article will attempt to set forth Leo XIII's doctrine on these questions - the cooperation of the two powers and societies, the substance of society, and public religion. The treatment of these questions will complete the Leonine concept of Christianity. It should then be possible, as a sort of by-product, to make some sort of judgment on the American situation.

${ }^{76}$ Encyclical, Inscrutabili, Desclée, I, 11. 